This Health Hazard Evaluation (HHE) report and any recommendations made herein are for the specific facility evaluated and may not be universally applicable. Any recommendations made are not to be considered as final statements of NIOSH policy or of any agency or individual involved. Additional HHE reports are available at http://www.cdc.gov/niosh/hhe/reports

HETA 96-0171-2692

\title{
Bureau of Alcohol, Tobacco, and Firearms
}

Washington, D.C.

\section{Gregory M. Kinnes \\ Gregg A. Hine}




\section{PREFACE}

The Hazard Evaluations and Technical Assistance Branch of NIOSH conducts field investigations of possible health hazards in the workplace. These investigations are conducted under the authority of Section 20(a)(6) of the Occupational Safety and Health Act of 1970, 29 U.S.C. 669(a)(6) which authorizes the Secretary of Health and Human Services, following a written request from any employer or authorized representative of employees, to determine whether any substance normally found in the place of employment has potentially toxic effects in such concentrations as used or found.

The Hazard Evaluations and Technical Assistance Branch also provides, upon request, technical and consultative assistance to Federal, State, and local agencies; labor; industry; and other groups or individuals to control occupational health hazards and to prevent related trauma and disease. Mention of company names or products does not constitute endorsement by the National Institute for Occupational Safety and Health.

\section{ACKNOWLEDGMENTS AND AVAILABILITY OF REPORT}

This report was prepared by Gregory M. Kinnes of the Hazard Evaluations and Technical Assistance Branch, Division of Surveillance, Hazard Evaluations and Field Studies (DSHEFS), NIOSH and Gregg A. Hine of the Washington Field Division, Bureau of Alcohol, Tobacco, and Firearms (ATF), Department of the Treasury. Field assistance was provided by Calvin K. Cook. Analytical support was provided by Ardith A. Grote and M. Eileen Birch of the Division of Physical Sciences and Engineering (DPSE), and Data Chem Laboratories, Inc. Desktop publishing was performed by Nichole L. Herbert. Review and preparation for printing was performed by Penny Arthur.

Copies of this report have been sent to employee and management representatives at ATF and the OSHA Regional Office. This report is not copyrighted and may be freely reproduced. Single copies of this report will be available for a period of three years from the date of this report. To expedite your request, include a self-addressed mailing label along with your written request to:

$$
\begin{gathered}
\text { NIOSH Publications Office } \\
\text { 4676 Columbia Parkway } \\
\text { Cincinnati, Ohio } 45226 \\
\text { 800-356-4674 }
\end{gathered}
$$

After this time, copies may be purchased from the National Technical Information Service (NTIS) at 5825 Port Royal Road, Springfield, Virginia 22161. Information regarding the NTIS stock number may be obtained from the NIOSH Publications Office at the Cincinnati address.

For the purpose of informing affected employees, copies of this report shall be posted by the employer in a prominent place accessible to the employees for a period of 30 calendar days. 


\title{
Health Hazard Evaluation Report 96-0171-2692 Bureau of Alcohol, Tobacco, and Firearms Washington, D.C. May 1998
}

\author{
Gregory M. Kinnes \\ Gregg A. Hine
}

\section{SUMMARY}

In April 1996, the National Institute for Occupational Safety and Health (NIOSH) received a request for a health hazard evaluation (HHE) from the Bureau of Alcohol, Tobacco, and Firearms (ATF), in Falls Church, Virginia, regarding respiratory hazards associated with fire investigations. ATF trains a select number of special agents as fire investigators as part of the ATF arson enforcement program. These special agents work with counterparts in state and local fire departments to investigate the origin and cause of fires. ATF special agents and local fire investigators in the northern Virginia jurisdictions were concerned about the potential respiratory health effects from conducting fire scene examinations and the adequacy of their respiratory protection.

In response to this request, environmental monitoring was performed during the investigation of two house fires on February 12 and 13, 1997, in metropolitan Washington, D.C., and Prince George's County, Maryland, and three staged fires on June 3, 1997, at the Fort Belvoir military base in Alexandria, Virginia. During these fire scene examinations, environmental samples were collected for total and respirable dust, metals, hydrogen cyanide, inorganic acids, aldehydes including formaldehyde, polycyclic aromatic hydrocarbons (PAHs), elemental carbon, and volatile organic compounds (VOCs).

The environmental monitoring indicated that low or trace concentrations, between the minimum detectable concentration (MDC) and minimum quantifiable concentration (MQC), were found for most of the analytes. However, formaldehyde was detected at concentrations up to 0.18 parts per million (ppm). Two formaldehyde samples collected during the staged fire scenes exceeded the NIOSH recommended exposure limit of $0.1 \mathrm{ppm}$ (ceiling). Low or trace concentrations of acetaldydehyde, acrolein, and furfural were also detected. NIOSH considers both formaldehyde and acetaldehyde to be potential occupational carcinogens and recommends that exposures be controlled to the lowest feasible concentration. Area air concentrations of hydrogen cyanide ranged from not detected to $0.04 \mathrm{ppm}$, while the concentrations for personal breathing zone (PBZ) samples ranged from a trace concentration to $0.03 \mathrm{ppm}$. Sulfuric acid was the only inorganic acid that had a concentration above the MQC, ranging from trace concentrations to 0.29 milligrams per cubic meter $\left(\mathrm{mg} / \mathrm{m}^{3}\right)$ of air. The major VOCs identified during these fire scenes were aliphatic hydrocarbons in the $\mathrm{C}_{9}$ and higher molecular weight range, acetone, acetic acid, ethyl acetate, isopropanol, styrene, benzene, toluene, xylene, styrene, furfural, phenol, and naphthalene. Several PAHs were also detected, and three of these are considered to have carcinogenic potential in humans. These included benz $(a)$ anthracene with concentrations ranging from 0.09-0.29 micrograms per cubic meter $\left(\mu \mathrm{g} / \mathrm{m}^{3}\right)$ of air, benzo $(b)$ fluoranthene with concentrations ranging from trace $-0.21 \mu \mathrm{g} / \mathrm{m}^{3}$, and benzo $(a)$ pyrene with concentrations ranging from $0.11-0.39 \mu \mathrm{g} / \mathrm{m}^{3}$. With the exception of the formaldehyde concentrations, all of these concentrations were well below the relevant evaluation criteria. 
Total and respirable dust were also detected at time-weighted average (TWA) concentrations up to 5.3 and $1.3 \mathrm{mg} / \mathrm{m}^{3}$, respectively. These concentrations were below their relevant evaluation criteria. However, peak total dust concentrations up to $30 \mathrm{mg} / \mathrm{m}^{3}$ were measured with a real-time portable dust monitor (Grimm); this indicated that excessive total and respirable dust concentrations were encountered for short durations during some activities. The mass median aerodynamic dust diameters extended from 6.1 micrometers $\left(\sigma_{\mathrm{g}}=3.1\right)$ to 12 micrometers $\left(\sigma_{\mathrm{g}}=\right.$ 2.5). These results indicated that dust generated during these activities can be respirable and inhalable.

Formaldehyde concentrations exceeding the NIOSH ceiling limit of $0.1 \mathrm{ppm}$ and exposures to several PAHs (which are suspected of having carcinogenic potential in humans) were measured. This indicates that fire investigator exposures to irritants which cause acute effects and carcinogens which have chronic effects are of concern. Total and respirable dust levels were detected at TWA concentrations up to 5.3 and $1.3 \mathrm{mg} / \mathrm{m}^{3}$, respectively, and peak concentrations up to $30 \mathrm{mg} / \mathrm{m}^{3}$ (total dust). A significant percentage of this measured mass was due to particle sizes in the respirable and inhalable range. Both the environmental sampling results and observations made during the five fire scene investigations indicated that the use of appropriate respiratory protection and mechanical ventilation equipment can reduce the potential for exposure. Several fire investigators, who did not wear respiratory protection, experienced both eye and respiratory irritation during these investigations.

Keywords: SIC 9221 (Police Protection) \& SIC 9224 (Fire Protection), arson investigators, fire investigators, fire scene investigations, fire fighting, overhaul, total dust, respirable dust, hydrogen cyanide, inorganic acids, aldehydes, formaldehyde, polycyclic aromatic hydrocarbons, PAHs, volatile organic compounds, VOCs, metals, elemental carbon, respiratory protection. 


\section{TABLE OF CONTENTS}

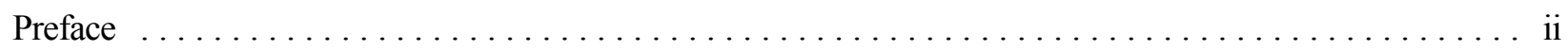

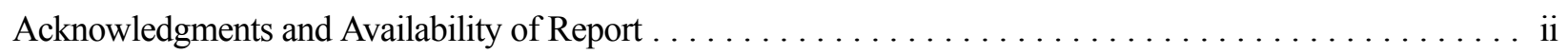

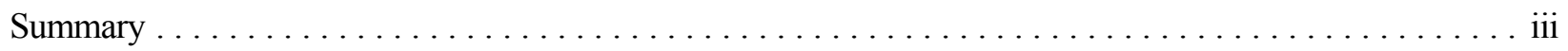

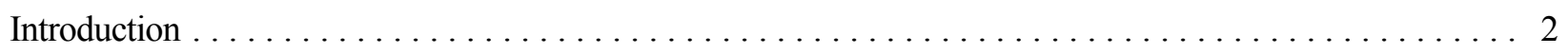

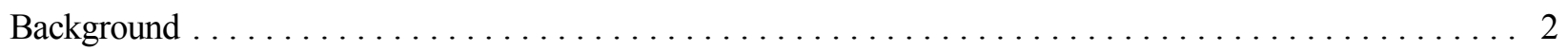

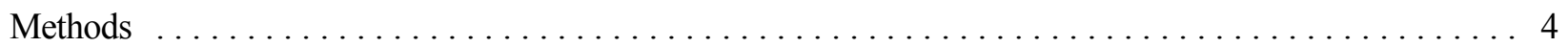

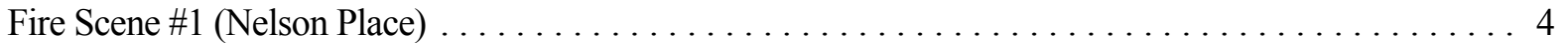

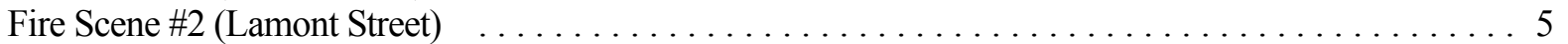

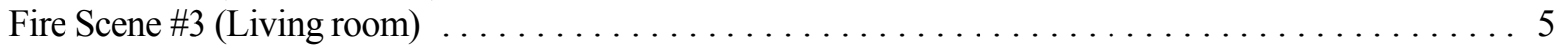

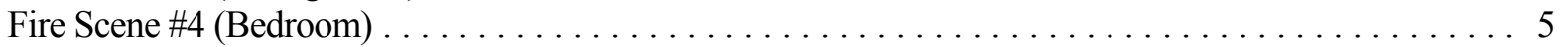

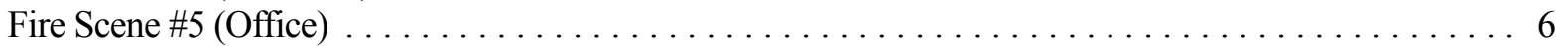

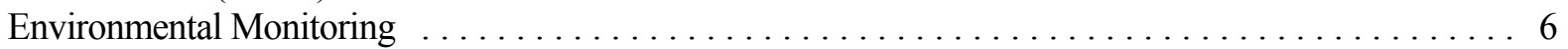

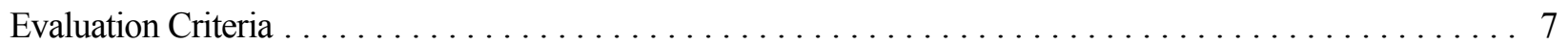

Results $\ldots \ldots \ldots \ldots \ldots \ldots \ldots \ldots \ldots \ldots \ldots \ldots \ldots \ldots \ldots \ldots \ldots \ldots \ldots \ldots$

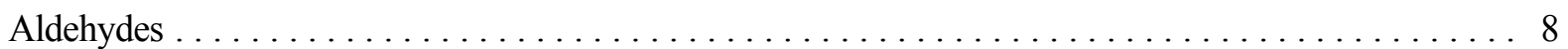

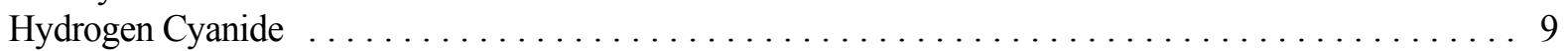

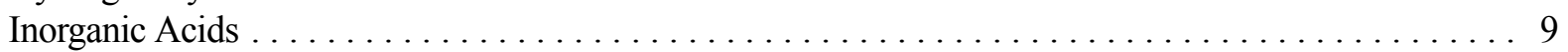

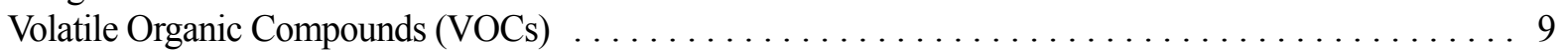

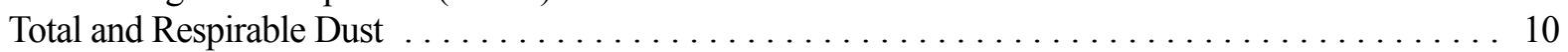

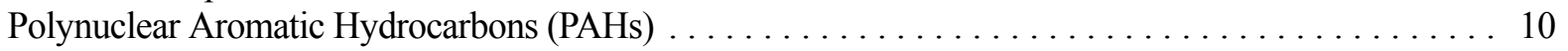

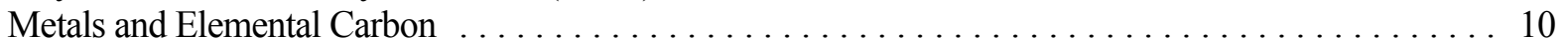

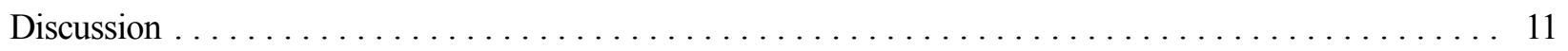

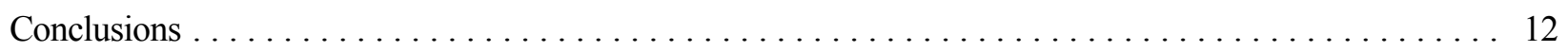

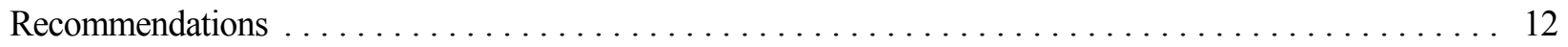

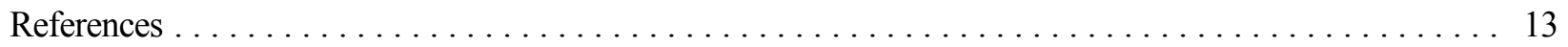




\section{INTRODUCTION}

In April 1996, the National Institute for Occupational Safety and Health (NIOSH) received a request for a health hazard evaluation (HHE) from the Bureau of Alcohol, Tobacco, and Firearms (ATF), in Falls Church, Virginia, regarding respiratory hazards associated with fire investigations. ATF trains a select number of special agents as fire investigators as part of the ATF arson enforcement program. These special agents work with counterparts in state and local fire departments to investigate the origin and cause of fires. ATF special agents and local fire investigators in the northern Virginia jurisdictions were concerned about potential respiratory health effects from conducting fire scene examinations and the adequacy of their respiratory protection.

In July 1996, a NIOSH industrial hygienist met with representatives from ATF, Fairfax County Virginia Fire Department (Fire Investigations Branch), and the National Fire Protection Association (NFPA) at the ATF Field Office in Falls Church, Virginia. During that meeting, the potential health hazards related to fire investigations were discussed. The safety and health of fire fighters has been studied in detail, however, only limited information is available concerning the hazards encountered by fire investigators. ${ }^{1}$ Since the request involved exposures not previously studied to any significant extent, the development of a preliminary sampling protocol whose results would promote further research into this subject was discussed. In addition, the possibility of incorporating the results of the investigation into the ATF Certified Fire Investigator (CFI) program was discussed. The NIOSH investigator subsequently accompanied ATF special agents on a walk-through of several fire scenes to get a better understanding of the post-fire environment.

In February 1997, a second visit to Washington, D.C., was made to conduct a preliminary assessment of the heath hazards encountered at fire scenes. On February 12 and 13, 1997, the NIOSH investigator accompanied an ATF special agent during responses to two house fires in metropolitan Washington, D.C., and Prince George's County, Maryland. Environmental air samples were collected during the fire scene examination for total and respirable dust, metals, hydrogen cyanide, inorganic acids, aldehydes including formaldehyde, polycyclic aromatic hydrocarbons(PAHs), elemental carbon, and volatile organic compounds (VOCs). These fire scene examinations were conducted within 30 minutes of the fires being extinguished, except for one involving a fatality where the examination was delayed for over two hours.

In June 1997, NIOSH investigators returned to Washington, D.C., after ATF secured access to an abandoned building on the Fort Belvoir military base in Alexandria, Virginia. On June 3, 1997, test burns were staged in three separate rooms within the building. NIOSH investigators were present during the examination of each fire scene by ATF special agents and local fire investigators. Environmental air samples were collected from each of the three burns by NIOSH investigators. In addition, thermal data acquisition equipment was used by ATF to record the fire behavior. Also present during the testing were two representatives from the NFPA.

\section{BACKGROUND}

A fire department's involvement at a fire scene typically occurs in three distinct phases; suppression, overhaul, and investigation. During the suppression phase, fire fighters are actively extinguishing the fire and ventilating the structure to remove heat and smoke. After the fire has been extinguished, fire fighters will search for hidden fire in walls, ceiling spaces, or other areas that are not easily accessible. This phase is termed overhaul and includes opening walls, pulling down ceiling materials, removing flooring, etc. to ensure that the fire has been completely extinguished. The final phase is the fire scene investigation which involves the determination of the origin and cause of the fire. Fire investigators will also determine whether the fire was accidental or incendiary in nature. Depending on the jurisdiction involved, the fire scene investigation can occur in conjunction with overhaul, where the investigators often direct the overhaul activities to ensure the 
preservation of evidence, or up to several days after the fire. In addition, several differences can occur in the way fire investigations are conducted, based on each jurisdiction's standard operating procedures.

With the increased use of synthetic materials in household and commercial products, fire investigators are frequently exposed to respiratory hazards while conducting fire scene investigations. In a typical structure fire, products containing plastics, foams, insulation, paints, and fibers are nearly always present. When these materials are involved in fire, they can liberate both gases and vapors, as well as aerosols, fibers (as from asbestos), metal fumes, and other particles. Occasionally, gases and vapors may be absorbed onto the surface of particles, and when inhaled may present a hazard from both the gas/vapor and particulate phase. ${ }^{2}$ While conducting fire scene examinations, investigators often observe suspended particulate material in the air and can be exposed to trapped vapors as they remove smoldering debris.

The International Association of Arson Investigators (IAAI) has identified several previous incidents in which fire investigators have been injured while performing their duties. ${ }^{3}$ The incidents typically involve fire investigators being overcome by combustion products at the fire scene and experiencing adverse respiratory symptoms. These types of exposures have reportedly occurred up to several days after the actual fire incident. The IAAI is also aware of member concerns regarding the occurrence of sinus and throat cancer that several fire investigators have attributed to exposures encountered at the fire scene. ${ }^{3}$ During the course of this investigation, another incident occurred which highlights the subject of hazards encountered by fire investigators. In April 1997, investigators from the Wilmington Fire Department and special agents from the ATF were conducting a fire scene investigation on the fourteenth floor of the Delaware Trust Building. While removing debris from a room, with limited ventilation, 14 investigators were overcome by an unknown vapor which caused headaches, nausea, and eye irritation. Although most of these investigators were wearing respirators, the type of cartridge (filter) in use was for particulate materials only, and did not protect them from the organic vapors.

Combustion products typically present at a fire scene include carbon monoxide, hydrogen cyanide, oxides of nitrogen, and aldehydes (formaldehyde). Some of these have good warning properties, such as odor, while others do not. Exposure to these contaminants can produce both acute (immediate) and chronic toxic effects. ${ }^{2}$ Respiratory hazards in the form of a gas, vapor, or particulate material are present at nearly all fire scenes and protection from these hazards should be considered. Research into respiratory hazards associated with fire fighting is not uncommon. However, this research was primarily focused on the exposure to toxic combustion gases during fire fighting and overhaul operations. While this research was extremely beneficial to fire fighters, and resulted in many departments establishing self-contained breathing apparatus (SCBA) standards, it did not address all the post-fire respiratory hazards that would be of concern to investigators. A more detailed description of the typical hazards encountered by fire fighters is presented in the Evaluation Criteria section.

Because fire investigators are often required to work for extended periods within the burned area as part of origin and cause determination, a SCBA is probably not their first choice of respiratory protection. Therefore, fire investigators may have a higher exposure risk to toxic products of combustion during investigative work than fire fighters who wear SCBAs during overhaul. ${ }^{4}$ However, many fire departments do not enforce or require the use of SCBAs during overhaul, which significantly increases a fire fighter's risk of exposure. In addition to working for extended periods in burned areas, fire investigators generally respond to more fires scenes than the average fire fighter. ${ }^{4}$ A 1991 NIOSH study involving exposures to fire fighters found that the greatest amount of particulate material was present after the fire was knocked down and during the fire overhaul phase. ${ }^{5}$ However, as the long term exposure risks to these hazards are unclear and undocumented, fire investigators typically limit their protective equipment to a helmet, coveralls, and gloves. Yet, some fire departments have recently issued 
respirators to fire investigators and established a protocol for its use. The Fairfax County Virginia Fire Department (FCFD) issued half face respirators to all fire investigators after conducting appropriate fit tests. The respirators are equipped with organic vapor/acid gas filters. ${ }^{6}$ In addition, the FCFD is considering a proposed revision in its current respirator policy to require SCBA use during all phases of overhaul. ${ }^{6}$

\section{METHODS}

The focus of this investigation was to characterize exposures that fire investigators may encounter at typical fire scenes. Initially, environmental sampling was to be performed at several fire scenes during the second visit (February 10-14, 1997). Before the visit, the ATF established contacts with several Washington, D.C., area fire departments to request their assistance in the notification of fires where environmental sampling would be appropriate and access to the fire scenes would be allowed. These fire departments included Washington, D.C., Prince George's and Montgomery counties in Maryland, the City of Alexandria, Virginia, and Fairfax and Arlington counties in Virginia. However, only two fires occurred during this period where typical fire scene investigations were warranted and environmental sampling would have been appropriate. This occurrence of limited fire scenes was also encountered during the initial visit (July 15-17, 1996). Since the occurrence of fires created a logistical problem, the ATF was able to secure access to an abandoned building on the Fort Belvoir Army Base in southern Fairfax County, Virginia. The Fort Belvoir Fire Department (FBFD) agreed for the building, which previously had asbestos removed and was to be demolished, to be used for staged fires.

The building used for the staged fires (Building 1837) was a $25 \times 90$ foot (ft), one-story wood frame structure, located on the Fort Belvoir Army Base. It was partitioned into numerous rooms and was formally used for administrative offices. The ceiling was a suspended tile system. The ATF furnished three rooms with various items to create scenarios that would be representative of typical fire scenes. For each of the three scenarios, the fires were initiated by a FBFD safety officer and allowed to burn. The FBFD then responded and extinguished each fire as part of their in-service training requirements, and each fire scene was examined to determine cause and origin. All three scenarios were treated as actual fire scenes.

Fire Scenes \#1 and \#2 were actual residential fires that occurred on February 12 \& 13, 1997, respectively. Environmental monitoring was conducted during the actual fire scene investigations at each site with the assistance of the responding fire departments. Fire Scene \#1 involved a two-story, four-unit, apartment building, while Fire Scene \#2 involved a one-story single family dwelling. Fire Scenes \#3 - \#5 were conducted on June 3, 1997, at Fort Belvoir. Three separate and distinct fires were initiated within Building 1837. Environmental air samples were collected during all five fire scene investigations. In addition, thermal data acquisition equipment was used by ATF to record the fire behavior by recording room temperatures at both the floor and ceiling levels during two of the staged fire scenes. Fire Scenes \#1 and \#2 were investigated by the responding fire department with assistance from an ATF special agent. Fire Scenes \#3 - \#5 were investigated by ATF special agents/certified fire investigators and an investigator from the Alexandria Virginia Fire Department.

\section{Fire Scene \#1 (Nelson Place)}

On the morning of February 12, 1997, a NIOSH investigator and special agents of ATF responded to a residential fire in the 3000 block of Nelson Street, SE, Washington, D.C. The D.C. Fire/EMS Department (DCFD) fire investigators determined that the fire was electrical in nature and originated on a second floor screened porch. Several pieces of furniture and miscellaneous household items were involved in the fire. Quantities of latex and oil base paint were stored on the porch and the contents were spilled onto the fire debris. Additional fire extension was observed to the interior of the dwelling and involved a small kitchen. Environmental air samples were taken during the origin and cause investigation. 
The monitoring equipment was placed in close proximity to the fire investigators during the investigation. A total of four investigators (DCFD and ATF) conducted the fire investigation, along with four to six DCFD fire fighters who assisted in removal of debris. However, as the fire occurred on a screened porch, the scene was extremely well ventilated and minimal particulate material and vapors were apparent.

\section{Fire Scene \#2 (Lamont Street)}

During the evening of February 13, 1997, a NIOSH investigator and ATF special agent responded to a residential fire on Lamont Street, Landover, Maryland. The fire primarily involved the living room of a one-story single family dwelling. A resident died in the fire as a result of smoke inhalation. Fire investigators from the Prince George's County Maryland Fire Department determined that the fire originated in the living room and was caused by the failure of lightweight extension cords that were placed beneath numerous layers of household materials and trash. The investigative phase was initiated approximately two hours after the fire was extinguished. During the investigation phase, numerous smoldering items were examined and removed by investigators. However, the living room area was well ventilated, due to the removal of a large bay window and a strong breeze. Environmental monitoring equipment was placed on a tripod located in the living room area during the fire scene examination. Due to the limited space in the living room, the monitoring equipment was placed several feet from the investigators.

\section{Fire Scene \#3 (Living room)}

At approximately 9:30 a.m., a fire was started in a $25 \times 18 \mathrm{ft}$ room at the west end of Building 1837 which was furnished with household materials (couch, chairs, television, stereo, tables, etc.) consistent with a living/family room. The interior wall surfaces consisted of wood paneling and the floor was carpeted. A fire fighter using a road flare, ignited the lower portion of a fabric covered recliner in the northeast corner of the room. The fire progressed to flashover, thus allowing the involvement of many of the materials within the room. After suppression of the fire, the room was mechanically ventilated with an electrical-powered smoke ejector and a gasoline-powered positive pressure fan for approximately thirty minutes before the roof was opened. Natural ventilation consisted of three windows, roof opening, and exterior entry door. After ventilation, the fire scene investigation was initiated and involved the examination and removal of smoldering fire debris by hand and with shovels. Most of the debris were relocated within the room. During the investigative phase, environmental monitoring equipment was placed on a tripod within the room and worn by investigators. Suspended particulate material was visible, as well as smoke from smoldering items.

\section{Fire Scene \#4 (Bedroom)}

At approximately 11:33 a.m., a fire was set in a $9 \mathrm{x}$ $13 \mathrm{ft}$ room located near the center of Building 1837 which was furnished with typical household materials, consistent with a bedroom. Ventilation for the room consisted of one single exterior window and the door. The interior wall surfaces were drywall and the floor was carpeted. A fire fighter using a road flare ignited a small pile of clothing which was placed on the floor between the south wall and the bed. The fire quickly involved adjacent combustible materials and vented at the open single window to the room. The fire continued to flashover, thus allowing the involvement of many of the materials within the room. Approximately four and a half minutes after ignition, ATF thermal data acquisition equipment recorded floor and ceiling temperatures of approximately $1400^{\circ} \mathrm{F}$. Fire suppression was initiated approximately seven minutes after ignition. After suppression was concluded, the room was mechanically ventilated for approximately 20 minutes. Four investigators conducted the fire scene examination and manipulated contents and debris by hand and shovel. Nearly all the contents were removed from the room and all debris were cleared from the floor. During 
the investigative phase, environmental monitoring equipment was placed within the room and on the investigators.

\section{Fire Scene \#5 (Office)}

At approximately 2:04 p.m., a fire was set in a $14 \mathrm{x}$ $25 \mathrm{ft}$ room at the east end of Building 1837 which was furnished with typical office materials (computers, printers, monitors, tables, paper, etc.). The interior walls were drywall and the floor was carpeted. The room had five single windows and an exterior door. Fire fighters used a road flare to ignite papers in several locations within the room. The fire quickly involved adjacent materials and initially vented at two windows to the south side of the structure. Approximately three minutes after ignition, the fire reached flashover and the fire then vented at all windows. ATF thermal data acquisition equipment recorded temperatures at that time of $1600^{\circ} \mathrm{F}$ at both the floor and ceiling. Approximately seven minutes after ignition, fire suppression activities were initiated. Upon suppression, the room was ventilated by mechanical means. All the contents of the room were involved in fire and sustained significant thermal damage. The fire investigation was conducted approximately 20 minutes after the fire was knocked down and involved the manipulation and removal of many smoldering items. Smoke and particulate material were very apparent during this fire scene examination. Various debris were relocated within the room by hand and shovel. During the investigative phase, environmental monitoring equipment was placed within the room and directly on the investigators' uniforms.

\section{Environmental Monitoring}

Many toxic chemical compounds may be generated and released during fires, and these can vary from fire to fire. ${ }^{7}$ Many variables control the resulting byproducts of combustion, the most important being the composition of the burning material. ${ }^{8,9}$ Other key factors include the temperature at which pyrolysis or combustion occurs, the concentration of oxygen present, and the efficiency of combustion. ${ }^{8,9}$

Environmental sampling was conducted for several of the possible contaminants present at the fire scene and focused on the contaminants most likely present during the investigation phase of a fire scene. Environmental sampling was not conducted for every possible contaminant due to the numerous analytical methods that would be involved. For example, monitoring was not conducted for carbon monoxide (CO) because some fire departments do not allow fire fighters to remove their SCBAs until a safety officer confirms that $\mathrm{CO}$ concentrations have fallen below a predetermined safe concentration by using directreading instruments. The FCFD requires that a safety officer determine the $\mathrm{CO}$ and oxygen concentrations and conduct a visual inspection of the current conditions (i.e., smoke and particulates) at the fire scene before allowing SCBAs to be doffed. ${ }^{6}$ The safe $\mathrm{CO}$ concentration used by the FCFD is 50 parts per million. ${ }^{6}$ The overhaul and investigation phases at a fire scene typically begin after the $\mathrm{CO}$ concentrations are considered safe. However, some fire departments discourage this practice because it may give the fire fighters a false sense of security and are beginning to require SCBA use during all overhaul activities.

Table 1 summarizes all of the air sampling methods used in this evaluation. ${ }^{10}$ Since Fire Scenes \#1 and \#2 involved the investigation of actual residential fires, only area samples were collected to minimize any disruption of the investigation. Both area and personal breathing zone (PBZ) samples were collected at Fire Scenes \#3, \#4, and \#5 since these fire scenes were staged. All the methods listed in Table 1 were utilized at all the fire scenes except elemental carbon, the quantitative analysis of VOCs, and the impinger method for formaldehyde. Samples for elemental carbon were only collected during Fire Scenes \#1 and \#2, while samples for the quantitative analysis of VOCs and formaldehyde using the impinger method were only collected during Fire Scenes \#3 - \#5.

Except for the samples obtained with the direct-reading instrument (Grimm), air samples were 
collected using calibrated battery-operated sampling pumps with the appropriate sorbent tube or filter media connected via Tygon ${ }^{\circledR}$ tubing. The area and personal breathing zone sample concentrations were calculated based on the actual monitoring time (time-weighted average [TWA-actual] concentrations) instead of calculating an 8-hour TWA concentration, so that the sampling data could be compared between the different scenes with unequal monitoring durations. Calibration of the air sampling pumps with the appropriate sampling media was performed daily, before and after each monitoring period. Field blanks were submitted to the laboratory for each analytical method.

\section{EVALUATION CRITERIA}

Fire fighters face many health hazards, including: inhalation of a wide variety of toxic combustion products; chemical exposures by direct skin and eye contact; physical hazards, including heat, cold, noise and falling objects; and exposure to carcinogenic chemicals or combustion products. In over 200 residential fires in Boston, airmonitoring (which focused on a small fraction of the possible combustion products) found varying air concentrations of carbon monoxide, carbon dioxide, hydrogen cyanide, benzene, nitrogen dioxide, hydrogen chloride, and acrolein. ${ }^{11,12}$ Other toxic components of smoke can include ammonia, acrylonitrile, halogen acids, sulphur dioxide, aldehydes, isocyanates, methylene chloride, particulates, and hydrocarbons. ${ }^{13,14,15}$

Exposure to respiratory irritants such as acrolein, hydrogen chloride, and nitrogen dioxide may lead to acute and chronic respiratory problems. Disability due to pulmonary disease has long been recognized as a potential work-related hazard for fire fighters. ${ }^{7}$ There is increasing concern about a fire fighter's exposures to carcinogens released from the combustion of synthetic materials used in building construction. ${ }^{7}$ This concern has been compounded by mortality and morbidity studies of fire fighters, which, although they have produced inconsistent evidence, have raised the possibility of increased risks from cardiovascular disease, respiratory disease, and cancers of the nervous, hematopoietic/lymphatic, respiratory, and gastrointestinal systems, which may be attributable to exposures to the components of smoke. ${ }^{16,17,18,19,20,21,22,23,24,25,26,27,28,29,30,31}$ Several recent studies have suggested an increased risk of: brain cancer among Washington fire fighters; brain, prostrate, colon, and lung cancer among Los Angeles fire fighters; and digestive tract cancers. ${ }^{25,27,29,32}$ Further studies are needed to better define these risks.

As a guide to the evaluation of the hazards posed by workplace exposures, NIOSH field staff employ environmental evaluation criteria for the assessment of a number of chemical and physical agents. These criteria are intended to suggest levels of exposure to which most workers may be exposed up to 10 hours per day, 40 hours per week for a working lifetime without experiencing adverse health effects. It is, however, important to note that not all workers will be protected from adverse health effects even though their exposures are maintained below these levels. A small percentage may experience adverse health effects because of individual susceptibility, a pre-existing medical condition, and/or a hypersensitivity (allergy). In addition, some hazardous substances may act in combination with other workplace exposures, the general environment, or with medications or personal habits of the worker to produce health effects even if the occupational exposures are controlled at the level set by the criterion. These combined effects are often not considered in the evaluation criteria. Also, some substances are absorbed by direct contact with the skin and mucous membranes, and thus potentially increase the overall exposure. Finally, evaluation criteria may change over the years as new information on the toxic effects of an agent become available.

The primary sources of environmental evaluation criteria for the workplace are: (1) NIOSH Recommended Exposure Limits (RELs) ${ }^{33}$, (2) the American Conference of Governmental Industrial Hygienists' (ACGIH $\left.{ }^{\circledR}\right)$ Threshold Limit Values $\left(\text { TLVs }^{\circledR}\right)^{34}$ and (3) the U.S. Department of Labor, OSHA Permissible Exposure Limits (PELs) ${ }^{35}$. 
In July 1992, the 11th Circuit Court of Appeals vacated the 1989 OSHA PEL Air Contaminants Standard. OSHA is currently enforcing the 1971 standards which are listed as transitional values in the current Code of Federal Regulations; however, some states operating their own OSHA-approved job safety and health programs continue to enforce the 1989 limits. NIOSH encourages employers to follow the 1989 OSHA limits, the NIOSH RELs, the ACGIH TLVs, or whichever are the more protective criterion. The OSHA PELs reflect the feasibility of controlling exposures in various industries where the agents are used, whereas NIOSH RELs are based primarily on concerns relating to the prevention of occupational disease. It should be noted when reviewing this report that employers are legally required to meet those levels specified by an OSHA standard and that the OSHA PELs included in this report reflect the 1971 values.

A time-weighted average (TWA) exposure refers to the average airborne concentration of a substance during a normal 8-to-10-hour workday. Some substances have recommended short-term exposure limits (STEL) or ceiling values which are intended to supplement the TWA where there are recognized toxic effects from higher exposures over the short-term.

A brief toxicity review and the exposure criteria for several of the contaminants that may be found at a given fire scene are included in Table 2. This list is not inclusive to all contaminants that may be found at a given fire scene, but represent the contaminants of particular concern due to their toxicity and their likelihood at fire scenes.

\section{RESULTS}

The results of the environmental monitoring are summarized in Tables 3, 4, and 5. Trace concentrations are defined as between the analytical limit of detection (LOD) and limit of quantitation (LOQ). The analytical LODs and LOQs for the environmental sampling methods used during this investigation are included in Table 6, along with the minimum detectable concentrations (MDCs) and minimum quantifiable concentrations (MQCs) which are calculated based on a representative sample volume. Low or trace concentrations were found for most of the analytes. However, formaldehyde was detected at concentrations up to 0.18 parts per million (ppm), and several PAHs were detected. Total and respirable dust were also detected at concentrations up to 5.3 and 1.3 milligrams per cubic meter $\left(\mathrm{mg} / \mathrm{m}^{3}\right)$ of air, respectively. The Grimm indicated that total dust peak concentrations up to $30 \mathrm{mg} / \mathrm{m}^{3}$ were possible. The results for each of the analytes are described in detail below.

\section{Aldehydes}

A summary of the air concentrations for formaldehyde, acetaldehyde, acrolein, and furfural are included in Table 3. Air concentrations of each contaminant were measured using a sorbent tube method that screens for these compounds. PBZ samples were collected during the staged fire scenes in addition to the area samples that were collected at all the fire scenes. The air concentrations of both formaldehyde and furfural measured with this method ranged from not detected to trace concentrations, while the air concentrations for acetaldehyde ranged from not detected to $0.13 \mathrm{ppm}$. Acrolein was detected on only one sample which had an air concentration of $0.02 \mathrm{ppm}$ at one of the actual fire scenes (\#2).

During the staged fire scenes, area samples for formaldehyde were also collected using an impinger method (NIOSH Method No. 3500). This analytical method can achieve a lower LOD than the sorbent tube method, but is usually not used for PBZ samples. The area formaldehyde concentrations for these samples ranged from 0.06 to $0.18 \mathrm{ppm}$.

All of the concentrations determined for acetaldehyde, acrolein, and furfural were below their relevant evaluation criteria. However, NIOSH considers acetaldehyde to be a potential occupational carcinogen and recommends that exposures be reduced to the lowest feasible concentration. Two of the formaldehyde samples collected using the impinger method had concentrations that exceeded the NIOSH recommended ceiling limit of $0.1 \mathrm{ppm}$. In addition, one PBZ sample collected using the 
sorbent tube method during a staged fire scene had a trace concentration. Both the MDC and MQC $(0.13$ and $0.43 \mathrm{ppm})$ for formaldehyde calculated for these samples also exceeded the NIOSH ceiling limit. Thus, the trace concentration for this PBZ sample would also have exceeded the ceiling limit. Although NIOSH has established numerical RELs for formaldehyde, NIOSH still recognizes formaldehyde as a potential occupational carcinogen and recommends that exposures be reduced to the lowest feasible concentration.

\section{Hydrogen Cyanide}

PBZ and area samples were collected for hydrogen cyanide. A summary of the air concentrations for these hydrogen cyanide samples is included in Table 3. The area air concentrations for hydrogen cyanide ranged from not detected to $0.04 \mathrm{ppm}$ while the concentrations for the PBZ samples ranged from a trace concentration to $0.03 \mathrm{ppm}$. All of these concentrations were well below the relevant evaluation criteria.

\section{Inorganic Acids}

A summary of the air concentrations for inorganic acids is included in Table 3. Sulfuric acid was the only inorganic acid that had a concentration that was above the MQC, which occurred in one sample. The sulfuric acid concentration for this sample was $0.29 \mathrm{mg} / \mathrm{m}^{3}$ and was collected as a PBZ sample during one of the staged fire scenes. The remaining samples only had trace concentrations of sulfuric acid. Hydrobromic and phosphoric acid were not detected on any of the samples, while only a trace concentration of nitric acid was detected on a sample from one of the actual fire scenes. Trace concentrations of hydrofluoric acid were detected on two samples for the staged fire scenes, and a trace concentration of hydrochloric acid was detected on one. All of the inorganic acid concentrations were below their relevant evaluation criteria.

\section{Volatile Organic Compounds (VOCs)}

Thermal desorption tubes were collected from each of the fire scenes, and were qualitatively analyzed to identify any VOCs. The major compounds identified during the actual fire scenes included aliphatic hydrocarbons in the $\mathrm{C}_{9}$ and higher molecular weight range, acetone, ethyl acetate, isopropanol, styrene, benzene, toluene, xylene, and naphthalene. Since several VOCs were identified from the actual fire scenes, a quantitative analysis was also performed from samples collected at the staged fire scenes. Two types of thermal desorption tubes were collected in conjunction with charcoal tubes. Select VOCs identified on the thermal tubes were then quantitatively analyzed using the charcoal tubes. The thermal desorption analysis of the samples from the staged fire scenes identified the major components as being benzene, toluene, furfural, styrene, naphthalene, phenol, and acetic acid. Several other minor components were also identified. Therefore, a quantitative analysis was performed for benzene, toluene, xylene, and styrene using the charcoal tubes (furfural concentrations were determined using the sorbent tubes from the aldehyde screen). A summary of the air concentrations from this analysis is included in Table 3. Only trace concentrations of benzene and toluene were detected on any of the charcoal tube samples. Xylene and styrene were not detected.

\section{Total and Respirable Dust}

The air concentrations of total and respirable dust are summarized in Table 3. Area samples were collected during each of the five fire scene investigations. The respirable dust concentrations ranged from not detected (less than $0.10 \mathrm{mg} / \mathrm{m}^{3}$ ) to $1.2 \mathrm{mg} / \mathrm{m}^{3}$ while the total dust concentrations ranged from 0.20 to $5.3 \mathrm{mg} / \mathrm{m}^{3}$. All the total and respirable dust concentrations were below the established evaluation criteria.

During the investigation of each of the fire scenes, a Grimm portable dust monitor was also used to measure dust concentrations. This instrument was used to obtain real-time concentrations and particle 
size distributions throughout the course of each investigation. These results are summarized in Table 4. The Grimm is a light scattering aerosol spectrometer which has eight channels to collect information for particle sizes greater than $0.75,1,2$, $3.5,5,7.5,10$, and 15 micrometers $(\mu \mathrm{m})$. Actual mass of the particulates was also calculated using a correction factor determined for each scene. This was accomplished by obtaining the actual total mass of the particles that passed through the spectrometer and were captured on a filter located in the instrument.

The real-time concentrations determined by the Grimm showed that significant amounts of the dust were generated by certain activities which caused short-term peaks. These data indicated that during each of the fire scene investigations several periods of low and high peak exposures occurred. This meant that a significant portion of the dust generated did not remain airborne for long periods of time. The data collected during the investigation of fire scene \#5 also indicated that peak levels of total dust concentrations up to $30 \mathrm{mg} / \mathrm{m}^{3}$ were encountered. The particle size distribution of the dust was also determined. The mass median aerodynamic diameters of the dust extended from 6.1 micrometers, with a geometric standard deviation $\left(\sigma_{g}\right)$ of 3.1, to 12 micrometers, with a $\sigma_{\mathrm{g}}$ of 2.5. The mass median aerodynamic diameter indicates the particle size where half of the sampled mass is due to particles below this diameter, and half of the sampled mass is due to particles above this diameter. Particle sizes up to $100 \mu \mathrm{m}$ are considered inhalable and can be deposited anywhere in the respiratory tract, whereas particle sizes up to $10 \mu \mathrm{m}$ can be deposited in the gas-exchange region of the lungs. ${ }^{34}$ These results indicate that dust generated during the fire scene investigations can be both respirable and inhalable.

\section{Polynuclear Aromatic Hydrocarbons (PAHs)}

A summary of the air concentrations for PAHs is included in Table 5. Only naphthalene, fluorene, and phenanthrene were detected during the two actual fire scenes. The naphthalene concentrations for these two samples were 30 and 36 micrograms per cubic meter $\left(\mu \mathrm{g} / \mathrm{m}^{3}\right)$ of air, while fluorene was detected at a trace concentration and $2.4 \mu \mathrm{g} / \mathrm{m}^{3}$. Only trace concentrations of phenanthrene were detected on these two samples. In contrast, only chrysene and benzo(e)pyrene were not detected during the staged fire scenes. The air concentrations for naphthalene, fluorene, and phenantrene for the staged fires ranged from $99-200 \mu \mathrm{g} / \mathrm{m}^{3}, 7.4-18 \mu \mathrm{g} / \mathrm{m}^{3}$, and $3.5-8.0$ $\mu \mathrm{g} / \mathrm{m}^{3}$, respectively. Three PAHs that the ACGIH includes on its list of industrial substances suspected of having carcinogenic potential in man were detected. ${ }^{34}$ These were $\operatorname{benz}(a)$ anthracene with concentrations ranging from $0.09-0.29 \mu \mathrm{g} / \mathrm{m}^{3}$, benzo $(b)$ fluoranthene with concentrations ranging from trace $-0.21 \mu \mathrm{g} / \mathrm{m}^{3}$, and benzo $(a)$ pyrene with concentrations ranging from $0.11-0.39 \mu \mathrm{g} / \mathrm{m}^{3}$. Numerical evaluation criteria for the individual PAHs have not been established with the exception of naphthalene. The concentrations for naphthalene were well below these established criteria. Since several PAHs have carcinogenic potential, exposures should be controlled to the lowest feasible concentration. The representative MDCs and MQCs are summarized in Table 5.

\section{Metals and Elemental Carbon}

The metal analysis did not detect the presence of any of the more toxic metals at significant concentrations. Most of these metals were not detected or present at analytical background levels. As was expected, the analysis for elemental carbon indicated that both organic and elemental carbon were present with elemental occurring at lower concentrations than organic carbon.

\section{DISCUSSION}

The environmental monitoring indicated that contaminant concentrations were generally greater during the staged fire scene investigations than the actual fire scene investigations. This was most likely due to the environment in which the actual fires occurred. Both of these sites were well ventilated. Fire Scene \#1 occurred in a porch addition to an 
apartment building. At the time of the fire investigation for this scene, there were no windows or screen structures remaining and it was open to the outside environment on three sides. For Fire Scene $\# 2$, the fire occurred in the living room area which had a large bay window. This window was removed during the course of the fire suppression activities. As a result, this room was well ventilated. In addition, the fire investigation for this scene focused on areas adjacent to this open window. Another factor that may have contributed to the lower contaminant concentrations was the 2-3 hour delay between the cessation of suppression activities and the beginning of the investigation. This fire scene involved a fatality which caused this delay. The investigation began within 30 minutes of the cessation of suppression activities for Fire Scene \#1 and within 10 minutes for Fire Scenes \#3, 4, and 5.

The environmental monitoring performed during the staged fire scenes did not indicate any significant differences in the results between the three different scenarios. These scenes were designed to simulate the different fuel sources that would be present in living rooms, bedrooms, and offices. Items present within a typical living room would contain wood furniture, furniture with foam cushions, televisions, stereos, and various lamps. A typical bedroom would likely contain similar furniture with the addition of a mattress, box spring, and more clothing items. Offices would also contain wood furniture with various electronic equipment including computers, printers, typewriters, facsimile machines, and various other business related items. This office scenario was designed to contain more plastics and other synthetic materials that are known to emit hazardous compounds when burned. Any significant differences between the contaminants released during these three scenarios were not observed, except for the higher total and respirable dust concentrations encountered during the office scenario.

Several observations were made during the investigations of these fire scenes. During the investigation of Fire Scene \#2, the investigators were kneeling while removing debris. On several occasions, smoke and dust was generated directly into the breathing zone of the fire investigator. For this scene, only area sampling was conducted with all of the sampling equipment attached to a tripod. This tripod was kept as close as possible to where the investigators were working. However, the tripod could not be moved close enough to simulate the investigators' breathing zone without disrupting the investigation. As stated previously, PBZ samples were not collected from the investigators at the actual fire scenes to minimize any disruption of these investigations. The investigators at this fire scene were most likely exposed to higher contaminant concentrations than the concentrations indicated by the environmental sampling. None of the investigators at the actual fire scenes wore respiratory protection, and several of them experienced some respiratory and eye irritation during the course of the investigation as evidenced by coughing and tearing. Some of the investigators at the staged fire scenes did wear half-face, air-purifying respirators with particulate filters. However, these investigators acknowledged that they had not been trained in the proper use of these respirators. One investigator, who was not wearing a respirator at the staged fire scenes, also experienced irritation of the eyes and respiratory tract.

\section{Conclusions}

Although the environmental sampling conducted during this investigation indicated that most contaminant concentrations did not exceed the relevant evaluation criteria, it still indicated that the potential for exposure exists. In addition, the sampling indicated that the potential for exposure to carcinogens existed to some extent. Exposures to formaldehyde concentrations which exceeded the NIOSH ceiling limit of $0.1 \mathrm{ppm}$ and to several PAHs (which are suspected of having carcinogenic potential in humans) were observed. This indicates that both acute and chronic exposures to fire investigators are of concern. Total and respirable dust were also detected at TWA concentrations up to 5.3 and $1.3 \mathrm{mg} / \mathrm{m}^{3}$, respectively. The Grimm 
portable dust analyzer indicated that peak concentrations of total dust up to $30 \mathrm{mg} / \mathrm{m}^{3}$ were possible and that a significant percentage of this measured mass was due to particle sizes in the respirable and inhalable range. Observations made during the five fire scene investigations indicated that the use of appropriate respiratory protection and mechanical ventilation equipment can significantly reduce the potential for exposure. Several fire investigators, who did not wear respiratory protection, experienced both eye and respiratory irritation during these investigations.

\section{RECOMMENDATIONS}

The contaminant concentrations measured during this investigation are not representative of all the potential exposures encountered by investigators because numerous factors are involved in contaminant generation in actual fire scenes. However, these results indicate that potential exposures encountered by fire investigators is a subject area which needs further research.

The following recommendations are based on the environmental sampling results and observations made during this investigation and are offered in the interest of improving health and safety conditions for ATF fire investigators. These recommendations would also be applicable to fire fighters involved in the overhaul of a fire scene.

1. The ATF should require their investigators to wear appropriate respiratory protection when performing fire scene investigations. Since the use of SCBAs would most likely not be practical during most fire scene investigations, the use of half-face, air-purifying respirators equipped with combination filter cartridges (high-efficiency particulate, VOCs, acid mists, and formaldehyde) or powered air-purifying respirators with the appropriate filter cartridges should be used. If half-face respirators are used, they should be used in conjunction with eye goggles to help prevent eye irritation.

2. The ATF should establish a respiratory protection program for their fire investigators and ensure that it complies with the requirements described in 29 CFR 1910.134. Publications developed by NIOSH, which should also be referenced, include the NIOSH Guide to Industrial Respiratory Protection and NIOSH Respirator Decision Logic. The written program should designate one individual with the responsibility for administering the respiratory protection program. The written respirator program should also contain information on the following topics: (a) the departments/operations which require respiratory protection; (b) the correct respirators required for each job/operation; (c) specifications that only NIOSH/MSHA approved respiratory devices shall be used; and (d) the criteria used for the proper selection, use, storage and maintenance of respirators, including limitations. A respiratory protection program should include the following elements:
a. written operating procedures
b. appropriate respirator selection
c. employee training
d. effective cleaning of respirators
e. proper storage
f. routine inspection and repair
g. exposure surveillance
h. program review
i. medical approval
j. use of approved respirators

All of these elements are discussed in more detail in the referenced materials.

3. The use of mechanical ventilation equipment that removes the contaminants from the areas where fire investigators are working should be utilized whenever possible. Alteration of the fire scene (removing windows, doors, etc.) that promotes natural ventilation should also be considered when it would not affect the preservation of the fire scene.

4. The use of other protective clothing should be implemented. To reduce the potential for contaminants being carried home by fire investigators, the use of disposable coveralls, boots, and gloves should be considered. If disposable items are not used, the laundering of any potentially 
contaminated clothing should be provided by a contractor who is aware of the contamination potential. The ATF should also train its fire investigators in the use of appropriate decontamination procedures utilized by emergency responders. ${ }^{36}$

\section{REFERENCES}

1. Orris P, Melius J, Duffy RM [1995]. Firefighters' safety and health. Occupational Medicine: State of the Art Reviews. Vol. 10, No. 4.

2. Anderson DA and Webb TL [1997]. Fire fighters' health and safety during overhaul operations. Occupational Health and Safety. August: pp. 44-45.

3. McDermott R [1996]. Letter of September 7, 1996, from Robert McDermott, Occupational Health and Safety Committee, International Association of Arson Investigators, to Ed Comeau, National Fire Protection Association.

4. Jarboe TL [1995]. An examination of toxicity hazards associated with the burning of materials commonly encountered by fire fighters. Research Paper Submitted to the National Fire Academy. February: p. 41.

5. Jankovic J, Jones W, Burkhart J, Noonan G [1991]. Environmental study of fire fighters. Ann Occup Hyg 35 (6):581-602.

6. Interview with Captain Will Snyder, Fairfax County, Virginia Fire Department, Fire Investigations Branch, February 13, 1997 and February 27, 1998.

7. Committee on Fire Toxicology [1986]. Fire and smoke: understanding the hazards. Washington: National Academy Press.

8. Terrill JB, Montgomery RR, Reinhardt CF [1978]. Toxic gases from fires. Science 200:1343-1347.
9. Zapp JA, Jr. [1951]. The toxicity of fire. Chemical Center, MD: Chemical Corps, Medical Division, (Special rep No 4.).

10. NIOSH [1994]. Eller PM, ed. NIOSH manual of analytical methods. $4^{\text {th }}$ rev. ed. Cincinnati, OH: U.S. Department of Health and Human Services, Public Health Service, Centers for Disease Control and Prevention, National Institute for Occupational Safety and Health, DHHS (NIOSH) Publication No. 94-113.

11. Treitman RD, Burgess WA, Gold A [1980]. Air contaminants encountered by fire fighters. Am Ind Hyg Assoc J 41:796-802.

12. Gold A, Burgess WA, Clougherty EV [1978]. Exposure of fire fighters to toxic air contaminants. Am Ind Hyg Assoc J 39:534-539.

13. Boettner EA, Ball G, Weiss B [1969]. Analysis of the volatile combustion products of vinyl plastics. J Appl Polymer Sci 13:377-395.

14. Montgomery RR, Reinhardt CF, Terrill JB [1975]. Combustion toxicology. J Fire Flammability Combustion Tox 2:179-185.

15. Hartzell GE, Packham SC, Switzer WG [1983]. Toxic products from fires. Am Ind Hyg Assoc J 44:248-255.

16. Mastromatteo E [1959]. Mortality in city firemen, II: a study of mortality in firemen of a city fire department. AM A Arch Ind Health 20:227-233.

17. Barnard RJ, Gardner GW, Diaco NV, et al. [1975]. Near-maximal ECG stress testing and coronary artery disease risk factor analysis in Los Angeles city fire fighters. J Occup Med 17:693-695.

18. Bates JT [1987]. Coronary artery disease deaths in the Toronto fire department. J Occup Med 29:132-135.

19. Unger KM, Snow RM, Mestas J, et al. [1980]. Smoke inhalation in firemen. Thorax 35:838-842. 
20. Peabody H [1977]. Pulmonary function and the fire fighters. J Combustion Tox 4:8-15.

21. Peters J, Theriault G, Fine L, et al. [1974]. Chronic effect of firefighting on pulmonary function. N Engl J Med 291:1320-1322.

22. Sparrow D, Bosse R, Rosner B, et al. [1982]. The effect of occupational exposure on pulmonary function: a longitudinal evaluation of fire fighters and non-fighters. Am Rev Respir Dis 125:319-322.

23. Douglas DB, Douglas RB, Oakes D, et al. [1985]. Pulmonary function of London firemen. Br J Ind Med 42:55-58.

24. Sidor R, Peters JM [1974]. Prevalence rates of chronic non-specific respiratory disease in fire-fighters. Am Rev Respir Dis 109:255-261.

25. NIOSH [1976]. Occupational mortality in Washington State 1950-71. Vol. III. Cincinnati, OH: U.S. Department of Health, Education, and Welfare, Public Health Service, Center for Disease Control, National Institute for Occupational Safety and Health, DHEW (NIOSH) Publication No. 76-175-C.

26. Enterline P, McKiever M [1963]. Differential mortality from lung cancer by occupation. J Occup Med 5:283-290.

27. NIOSH [1980]. Occupational mortality in the State of California 1959-1961. Cincinnati, OH: U.S. Department of Health and Human Services, Public Health Service, Center for Disease Control, National Institute for Occupational Safety and Health, DHHS (NIOSH) Publication No. 80-104.

28. Feuer E, Rosenman K [1986]. Mortality in police and fire fighters in New Jersey. Am J Ind Med 9:517-527.

29. Lewis SS, Bierman HR, Faith MR [1983]. Cancer mortality among Los Angeles City fire fighters: report to the Los Angeles fire department. Beverly Hills, CA: Institute for Cancer and Blood Research.
30. NIOSH [1983]. Hazard evaluation and technical assistance report: Chester Fire Department, Chester, PA. Cincinnati, OH: U.S. Department of Health and Human Services, Public Health Service, Center for Disease Control, National Institute for Occupational Safety and Health, NIOSH Report No. HETA 83-360-1495.

31. Abrams JL [1974]. Occupational mortality among professional fire fighters [Dissertation]. Oklahoma City, OK: University of Oklahoma.

32. Demers PA, Heyer NJ, Rosenstock L [1992]. Mortality among fire fighters from three Northwestern United States cities. Br J Ind Med 49:664-670.

33. NIOSH [1992]. Recommendations for occupational safety and health: compendium of policy documents and statements. Cincinnati, $\mathrm{OH}$ : U.S. Department of Health and Human Services, Public Health Service, Centers for Disease Control, National Institute for Occupational Safety and Health, DHHS (NIOSH) Publication No. 92-100.

34. ACGIH [1997]. 1997 TLVs ${ }^{\circledR}$ and BEIs $®$ : threshold limit values for chemical substances and physical agents and biological exposure indices. Cincinnati, $\mathrm{OH}$ : American Conference of Governmental Industrial Hygienists.

35. Code of Federal Regulations [1989]. 29 CFR 1910.1000. Washington, DC: U.S. Government Printing Office, Federal Register.

36. Tokle G [1993]. Hazardous materials response handbook. $2^{\text {nd }}$ edition. Quincy, Massachusetts: National Fire Protection Association. 


\begin{tabular}{|c|c|c|c|c|}
\hline \multicolumn{5}{|c|}{$\begin{array}{c}\text { Table 1 } \\
\text { Summary of Sampling and Analytical Methods } \\
\text { Bureau of Alcohol, Tobacco, and Firearms, Washington, D.C. (HETA 96-0171) }\end{array}$} \\
\hline Substance & $\begin{array}{l}\text { Flow Rate } \\
(\text { Lpm) }\end{array}$ & Sample Media & Analytical Method & Comments \\
\hline Hydrogen Cyanide & 0.2 & $\begin{array}{l}\text { Soda lime sorbent tubes ( } 600 \mathrm{mg} \text { front } \\
\text { section/200 mg back section) }\end{array}$ & $\begin{array}{l}\text { NIOSH Method No. } 6010 \text { modified for analysis on a } \\
\text { Technicon Autoanalyzer II-C using visible absorption } \\
\text { spectrophotometry }\end{array}$ & $\begin{array}{l}\text { The glass wool plug that presides the sorbent } \\
\text { was removed prior to sampling }\end{array}$ \\
\hline Acids, Inorganic & 0.2 & Orbo ${ }^{\mathrm{TM}} 53$ sorbent tubes & $\begin{array}{l}\text { NIOSH Method No. 7903, analysis by ion } \\
\text { chromatography }\end{array}$ & $\begin{array}{l}\text { Analysis provides results for hydrofluoric, } \\
\text { hydrochloric, nitric, phosphoric, sulfuric, and } \\
\text { hydrobromic acids. }\end{array}$ \\
\hline Aldehydes & 0.1 & $\begin{array}{l}10 \% 2-\text { (hydroxymethyl)piperidine on } \\
\text { XAD-2 sorbent tubes ( } 120 \mathrm{mg} \text { front } \\
\text { section } / 60 \mathrm{mg} \text { back section) }\end{array}$ & $\begin{array}{l}\text { NIOSH Method No. 2539, analysis by GC-FID with } \\
\text { modifications }\end{array}$ & $\begin{array}{l}\text { Analysis provides results for formaldehyde, } \\
\text { acetaldehyde, acrolein, and furfural. }\end{array}$ \\
\hline Formaldehyde & 1 & $\begin{array}{l}\text { Impinger with } 20 \mathrm{~mL} \text { of } 1 \% \text { sodium } \\
\text { bisulfite solution }\end{array}$ & $\begin{array}{l}\text { NIOSH Method No. 3500, analysis by visible } \\
\text { spectroscopy }\end{array}$ & $\begin{array}{l}\text { This method can detect lower concentrations } \\
\text { of formaldehyde than the aldehyde method. }\end{array}$ \\
\hline $\begin{array}{l}\text { Polycyclic Aromatic } \\
\text { Hydrocarbons } \\
\text { (PAHs) }\end{array}$ & 2.0 & $\begin{array}{l}\text { Zefluor filter }(37 \mathrm{~mm} \text { diameter, } 2 \mu \mathrm{m} \\
\text { pore size), followed by an ORBO } 42 \\
\text { sorbent tube }\end{array}$ & $\begin{array}{l}\text { NIOSH Method No. 5506, analysis by HPLC with } \\
\text { modifications }\end{array}$ & $\begin{array}{l}\text { Filter cassettes and sorbent tube holders were } \\
\text { wrapped with aluminum foil to prevent the } \\
\text { degradation of PAHs by ultraviolet light. }\end{array}$ \\
\hline $\begin{array}{l}\text { Qualitative Volatile } \\
\text { Organic Compound } \\
\text { (VOC) Screen }\end{array}$ & 0.02 & Thermal desorption tubes & $\begin{array}{l}\text { Samples analyzed using the Tekmar thermal desorber } \\
\text { interfaced directly to a gas chromatograph and a mass } \\
\text { spectrometry detector (GC/MS). }\end{array}$ & $\begin{array}{l}\text { Each thermal desorption (TD) tube contains } \\
\text { three beds of sorbent materials: (1) a front } \\
\text { layer of Carbotrap C; (2) a middle layer of } \\
\text { Carbotrap; and (3) a back section of } \\
\text { Carbosieve S-III. }+\end{array}$ \\
\hline $\begin{array}{c}\text { Quantitative } \\
\text { Analysis for } \\
\text { Selected Solvents }\end{array}$ & 0.2 & $\begin{array}{l}\text { Activated charcoal sorbent tubes } \\
\text { (100 mg front section/50 mg back } \\
\text { section) }\end{array}$ & $\begin{array}{c}\text { Since the major VOCs identified by the GC/MS analysis } \\
\text { of the thermal tubes were aromatic hydrocarbons, NIOSH } \\
\text { Method No. } 1501 \text {, analysis by GC-FID with } \\
\text { modifications, was used. }\end{array}$ & $\begin{array}{l}\text { Specific VOCs that were quantified included } \\
\text { benzene, toluene, xylenes, and styrene. }\end{array}$ \\
\hline Elements (metals) & 2.0 & $\begin{array}{c}\text { MCE filter ( } 37 \mathrm{~mm} \text { diameter, } 0.8 \mu \mathrm{m} \\
\text { pore size })\end{array}$ & NIOSH Method No. 7300, analysis by ICP & This analysis provides results for 27 elements. \\
\hline
\end{tabular}




\begin{tabular}{|c|c|c|c|c|c|}
\hline \multicolumn{6}{|c|}{$\begin{array}{c}\text { Table } 1 \text { (continued) } \\
\text { Summary of Sampling and Analytical Methods } \\
\text { Bureau of Alcohol, Tobacco, and Firearms, Washington, D.C. (HETA 96-0171) }\end{array}$} \\
\hline Substance & $\begin{array}{l}\text { Flow Rate } \\
\text { (Lpm) }\end{array}$ & Sample Media & Analytical $N$ & Method & Comments \\
\hline Total Particulate & 2.0 & $\begin{array}{l}\text { Tared PVC filter }(37 \mathrm{~mm} \text { diameter, } \\
\quad 0.8 \mu \mathrm{m} \text { pore size })\end{array}$ & NIOSH Method No. 0500, & , Gravimetric analysis & $\begin{array}{l}\text { Samples were collected with closed-face } \\
\text { filter cassettes }\end{array}$ \\
\hline $\begin{array}{l}\text { Respirable } \\
\text { Particulate }\end{array}$ & 1.7 & $\begin{array}{l}\text { Tared PVC filter ( } 37 \mathrm{~mm} \text { diameter, } \\
0.8 \mu \mathrm{m} \text { pore size })\end{array}$ & NIOSH Method No. 0600, & , Gravimetric analysis & $\begin{array}{l}\text { Dorr-Oliver nylon cyclone used as particle } \\
\text { size selector }\end{array}$ \\
\hline $\begin{array}{l}\text { Grimm Portable } \\
\text { Dust Monitoring }\end{array}$ & 1.2 & $\begin{array}{l}\text { Dust is collected through a probe } \\
\text { directly into the instrument. }\end{array}$ & $\begin{array}{l}\text { The Grimm Dust Monitor is a } \\
\text { spectrometer designed for } \\
\text { measurement with particle }\end{array}$ & $\begin{array}{l}\text { a light scattering aerosol } \\
\text { real-time particulate } \\
\text { e size discrimination. }\end{array}$ & $\begin{array}{l}\text { Eight channels collect count information for } \\
\text { particle sizes greater than } 0.75,1,2,3.5,5 \text {, } \\
7.5,10 \text {, and } 15 \text { micrometers }(\mu \mathrm{m}) \text {. }\end{array}$ \\
\hline $\begin{array}{l}\text { Elemental/Organic } \\
\text { Carbon }\end{array}$ & 2.0 & Quartz-fiber filters (37 mm diameter) & $\begin{array}{l}\text { A rectangular punch }\left(1.54 \mathrm{~cm}^{2}\right. \\
\text { filter for a three stage thern }\end{array}$ & $\begin{array}{l}\left.{ }^{2}\right) \text { is taken from the quartz } \\
\text { mal-optical analysis. }\end{array}$ & $\begin{array}{l}\text { Samples were collected using a closed-face } \\
\text { cassette instead of opened-face. }\end{array}$ \\
\hline \multicolumn{6}{|c|}{ t A second type of thermal desorption tube containing one bed of Tenax-GR sorbent material was also used during sampling at the Ft. Belvoir staged fire scenes. } \\
\hline \multicolumn{6}{|c|}{ The following are abbreviations which were not spelled out in the table. } \\
\hline $\begin{array}{ll}\mathbf{L p m} & = \\
\mathbf{m g} & = \\
\mathbf{m m} & = \\
\mu \mathbf{m} & = \\
\mathbf{c m}^{2} & = \\
\text { GC-FID } & =\end{array}$ & \multicolumn{2}{|c|}{$\begin{array}{l}\text { Liters per minute } \\
\text { milligram } \\
\text { millimeter } \\
\text { micrometer } \\
\text { square centimeter } \\
\text { Gas chromatography-flame ionization detector }\end{array}$} & $\begin{array}{l}\text { HPLC } \\
\text { Zefluor } \\
\text { MCE } \\
\text { ICP } \\
\text { PVC }\end{array}$ & \multicolumn{2}{|c|}{$\begin{array}{l}\text { High pressure liquid chromatography } \\
\text { Teflon }{ }^{\circledR} \text { sampling filter } \\
\text { Mixed cellulose ester } \\
\text { inductively coupled plasma emission spectrometry } \\
\text { Polyvinyl chloride }\end{array}$} \\
\hline
\end{tabular}


Table 2

Toxicity and Exposure Criteria Information

Bureau of Alcohol, Tobacco, and Firearms, Washington, D.C. (HETA 96-0171)

\begin{tabular}{|c|c|c|c|c|}
\hline Compound & Toxicity Review* & $\begin{array}{c}\text { NIOSH } \\
\text { REL }\end{array}$ & $\begin{array}{l}\text { OSHA } \\
\text { PEL }\end{array}$ & $\begin{array}{c}\text { ACGIH } \\
\text { TLV }\end{array}$ \\
\hline $\begin{array}{l}\text { Hydrogen } \\
\text { Cyanide }\end{array}$ & $\begin{array}{l}\text { Rapid death due to metabolic asphyxiation (impairs the body's ability to } \\
\text { utilize oxygen). Less severe exposures cause weakness, headache, } \\
\text { confusion, fatigue, and other central nervous system effects. Hydrogen } \\
\text { cyanide has been recognized in significant concentrations in some fires, as a } \\
\text { combustion product of wool, silk, and many synthetic polymers; it may play } \\
\text { a role in toxicity and deaths from smoke inhalation. }\end{array}$ & $\begin{array}{l}4.7 \mathrm{ppm} \\
\text { STEL (S) }\end{array}$ & $\begin{array}{c}10 \text { ppm TWA } \\
\text { (S) }\end{array}$ & $\begin{array}{c}4.7 \mathrm{ppm} \text { ceiling } \\
\text { (S) }\end{array}$ \\
\hline Benzene & $\begin{array}{l}\text { Acute benzene overexposure can cause central nervous system depression } \\
\text { with symptoms such as headache, nausea, and drowsiness. Chronic } \\
\text { exposure to benzene has been associated with the depression of the } \\
\text { hematopoietic system and is associated with an increased incidence of } \\
\text { leukemia and possibly multiple myeloma. NIOSH classifies benzene as a } \\
\text { human carcinogen. }\end{array}$ & $\begin{array}{c}0.1 \text { ppm TWA } \\
\text { 1ppm STEL } \\
\mathbf{C a}^{\ddagger}\end{array}$ & $\begin{array}{l}1 \text { ppm TWA } \\
5 \text { ppm STEL }\end{array}$ & $\begin{array}{c}0.5 \text { ppm TWA } \\
2.5 \text { ppm STEL } \\
\text { (S), Ca }\end{array}$ \\
\hline $\begin{array}{c}\text { Acids, } \\
\text { Inorganic }\end{array}$ & $\begin{array}{l}\text { Inorganic acids are primary irritants and are corrosive in high } \\
\text { concentrations. Inorganic acids will cause chemical burns when in contact } \\
\text { with the skin and mucous membranes, and are a particular hazard if contact } \\
\text { with the eye should occur. Vapors and mists are respiratory tract irritants, } \\
\text { and some inorganic acids may cause pulmonary edema. Discoloration or } \\
\text { erosion of the teeth may also occur in exposed workers. Ingestion of } \\
\text { inorganic acids will result in severe throat and stomach destruction. }\end{array}$ & $\begin{array}{c}\mathbf{H}_{\mathbf{2}} \mathbf{S O}_{\mathbf{4}} \\
1 \mathrm{mg} / \mathrm{m}^{3} \mathrm{TWA} \\
\mathbf{H C l} \\
5 \mathrm{ppm} \text { ceiling } \\
\mathbf{H F} \\
3 \text { ppm TWA } \\
6 \text { ppm STEL }\end{array}$ & $\begin{array}{c}\mathbf{H}_{2} \mathbf{S O}_{4} \\
1 \mathrm{mg} / \mathrm{m}^{3} \mathrm{TWA} \\
\mathbf{H C l} \\
5 \mathrm{ppm} \text { ceiling } \\
\mathbf{H F} \\
3 \mathrm{ppm} \text { TWA }\end{array}$ & $\begin{array}{c}\mathbf{H}_{2} \mathbf{S O}_{4} \\
1 \mathrm{mg} / \mathrm{m}^{3} \text { TWA } \\
3 \mathrm{mg} / \mathrm{m}^{3} \text { STEL } \\
\mathbf{H C l} \\
5 \mathrm{ppm} \text { ceiling } \\
\mathbf{H F} \\
3 \mathrm{ppm} \text { ceiling }\end{array}$ \\
\hline Acetaldehyde & $\begin{array}{l}\text { Acetaldehyde is an irritant of the eyes, skin, and respiratory tract; at high } \\
\text { concentrations it causes narcosis. The irritant effects of the vapor at lower } \\
\text { concentrations, such as cough and a burning sensation in the nose, throat, } \\
\text { and eyes, usually prevent exposure sufficient to cause central nervous } \\
\text { system depression or chronic effects. It is carcinogenic in experimental } \\
\text { animals and is considered to be a probable human carcinogen. }\end{array}$ & $\mid \begin{array}{c}\mathbf{C a} \\
\begin{array}{c}\text { No numerical REL } \\
\text { established }\end{array}\end{array}$ & 200 ppm TWA & 25 ppm ceiling \\
\hline
\end{tabular}




\begin{tabular}{|c|c|c|c|c|}
\hline \multicolumn{5}{|c|}{$\begin{array}{c}\text { Table } 2 \text { (continued) } \\
\text { Toxicity and Exposure Criteria Information } \\
\text { Bureau of Alcohol, Tobacco, and Firearms, Washington, D.C. (HETA 96-0171) }\end{array}$} \\
\hline Compound & Toxicity Review* & $\begin{array}{l}\text { NIOSH } \\
\text { REL }\end{array}$ & $\begin{array}{c}\text { OSHA } \\
\text { PEL }\end{array}$ & $\begin{array}{c}\text { ACGIH } \\
\text { TLV }\end{array}$ \\
\hline Acrolein & $\begin{array}{l}\text { Acrolein is an intense irritant of the eyes and upper respiratory tract. } \\
\text { Exposure to high concentrations may cause tracheobronchitis and } \\
\text { pulmonary edema. The irritation threshold in man is } 0.25 \mathrm{ppm} \text { to all } \\
\text { mucous membranes within } 5 \text { minutes. Fatalities have been reported at } \\
\text { levels as low as } 10 \mathrm{ppm} \text {, and } 150 \mathrm{ppm} \text { is lethal after } 10 \text { minutes. The violent } \\
\text { irritant effect usually prevents chronic toxicity in man. Prolonged or } \\
\text { repeated contact produces skin irritation, burns, and sometimes sensitization. }\end{array}$ & $\begin{array}{l}0.1 \mathrm{ppm} \text { TWA } \\
0.3 \mathrm{ppm} \text { STEL }\end{array}$ & $0.1 \mathrm{ppm}$ TWA & $\begin{array}{l}0.1 \text { ppm TWA } \\
0.3 \text { ppm STEL } \\
\begin{array}{l}\text { Notice of Intended } \\
\text { Changes: } 0.1 \text { ppm } \\
\text { ceiling limit }\end{array}\end{array}$ \\
\hline Furfural & $\begin{array}{l}\text { Furfural is an irritant of the eyes, mucous membranes, and skin and is a } \\
\text { central nervous system depressant. Although the vapor is an irritant, the } \\
\text { liquid has a relatively low volatility so that inhalation of significant } \\
\text { quantities is unlikely. Exposure to levels of } 1.9 \text { to } 14 \text { ppm can cause eye and } \\
\text { throat irritation and headache. The liquid or vapor is irritating to the skin } \\
\text { and may cause dermatitis, allergic sensitization, and photosensitization. }\end{array}$ & $\mathrm{n} / \mathrm{a}$ & $\begin{array}{l}5 \text { ppm TWA } \\
\text { (S) }\end{array}$ & $\begin{array}{l}2 \text { ppm TWA } \\
\text { (S) }\end{array}$ \\
\hline $\begin{array}{l}\text { Polynuclear } \\
\text { Aromatic } \\
\text { Hydrocarbons } \\
\text { (PAHs) }\end{array}$ & $\begin{array}{l}\text { Polynuclear aromatic hydrocarbons refers to a set of cyclic organic } \\
\text { compounds that consist of two or more fused aromatic rings that may have } \\
\text { sulfur, nitrogen, or oxygen in the ring structure and alkyl substituted cyclics. } \\
\text { They are often associated with the combustion or pyrolysis of organic } \\
\text { matter, especially coal, wood, and petroleum products. PAHs have received } \\
\text { considerable attention since some have been shown to be carcinogenic in } \\
\text { experimental animals. NIOSH investigators have hypothesized that PAHs } \\
\text { with } 2 \text { to } 3 \text { rings are associated with more irritative effects, while the } 4 \text { to } 7 \\
\text { ring PAHs may have more carcinogenic and/or mutagenic effects. It is not } \\
\text { currently possible to definitively distinguish between these two PAH groups } \\
\text { analytically. }\end{array}$ & \multicolumn{3}{|c|}{ None established for PAHs as a class. } \\
\hline $\begin{array}{c}\text { Total } \\
\text { Particulate }\end{array}$ & $\begin{array}{l}\text { Total particulate is a measure of all airborne particulate which was collected } \\
\text { on the sample filter. Often the chemical composition of the airborne } \\
\text { particulate does not have an established occupational health exposure } \\
\text { criterion. It has been the convention to apply a generic exposure criterion in } \\
\text { such cases. Formerly referred to as nuisance dust, the preferred terminology } \\
\text { for the non-specific particulate ACGIH TLV criterion is now "particulates, } \\
\text { not otherwise classified (n.o.c.), " [or "not otherwise regulated" (n.o.r.) for } \\
\text { the OSHA PEL]. }\end{array}$ & $\mathrm{n} / \mathrm{a}$ & $15 \mathrm{mg} / \mathrm{m}^{3} \mathrm{TWA}$ & $\begin{array}{c}10 \mathrm{mg} / \mathrm{m}^{3} \mathrm{TWA} \\
\text { as Inhalable } \\
\text { fraction }\end{array}$ \\
\hline $\begin{array}{l}\text { Respirable } \\
\text { Particulate }\end{array}$ & $\begin{array}{l}\text { In contrast to total particulate, a respirable particulate sample uses a } \\
\text { selection device to obtain the fraction of the airborne particulate that is small } \\
\text { enough to be retained in the respiratory system once inhaled. } \\
\text { Any conclusions based on respirable (or total) particulate concentrations } \\
\text { may be misleading since other potentially toxic substances may be present. } \\
\text { These particulate concentrations, along with the results obtained from tests } \\
\text { for individual components (such as PAHs and metals) should be considered } \\
\text { together when determining the degree of hazard. }\end{array}$ & $\mathrm{n} / \mathrm{a}$ & $5 \mathrm{mg} / \mathrm{m}^{3} \mathrm{TWA}$ & $3 \mathrm{mg} / \mathrm{m}^{3}$ TWA \\
\hline
\end{tabular}




\begin{tabular}{|c|c|c|c|c|}
\hline \multicolumn{5}{|c|}{$\begin{array}{c}\text { Table } 2 \text { (continued) } \\
\text { Toxicity and Exposure Criteria Information } \\
\text { Bureau of Alcohol, Tobacco, and Firearms, Washington, D.C. (HETA 96-0171) }\end{array}$} \\
\hline Compound & Toxicity Review* & $\begin{array}{c}\text { NIOSH } \\
\text { REL }\end{array}$ & $\begin{array}{c}\text { OSHA } \\
\text { PEL }\end{array}$ & $\begin{array}{c}\text { ACGIH } \\
\text { TLV }\end{array}$ \\
\hline Asbestos & $\begin{array}{l}\text { Asbestos causes chronic lung disease (asbestosis), inflammation of the } \\
\text { pleura, and certain cancers of the lung, including mesothelioma, and } \\
\text { digestive tract. Although NIOSH has established an REL, it considers } \\
\text { asbestos (i.e., actinolite, amosite, anthophyllite, chrysotile, crocidolite, and } \\
\text { tremolite) to be a potential occupational carcinogen and recommends that } \\
\text { exposures be reduced to the lowest feasible concentration. }\end{array}$ & $\begin{array}{l}0.1 \text { fiber/cc } \\
\text { 100-minute } \\
\text { TWA } \\
\text { Ca }\end{array}$ & $\begin{array}{l}0.1 \text { fiber/cc } \\
\text { TWA } \\
1.0 \text { fiber/cc } \\
\text { excursion }\end{array}$ & $\begin{array}{c}0.2-2 \text { fibers } / \mathrm{cc} \\
\text { for various foms } \\
0.1 \text { fibers } / \text { cc for } \\
\text { all forms } \\
\text { (proposed } \\
\text { change), Ca }\end{array}$ \\
\hline $\begin{array}{c}\text { Carbon } \\
\text { Monoxide }\end{array}$ & $\begin{array}{l}\text { Carbon monoxide }(\mathrm{CO}) \text { combines with hemoglobin and interferes with the } \\
\text { oxygen carrying capacity of blood. Symptoms include headache, } \\
\text { drowsiness, dizziness, nausea, vomiting, collapse, myocardial ischemia, and } \\
\text { death. }\end{array}$ & $\begin{array}{c}35 \text { ppm TWA } \\
200 \text { ppm ceiling }\end{array}$ & 50 ppm TWA & 25 ppm TWA \\
\hline Arsenic & $\begin{array}{l}\text { Acute inhalation exposures to arsenic have resulted in irritation of the upper } \\
\text { respiratory tract, even leading to nasal perforations. Chronic exposure can } \\
\text { cause weakness, nausea, vomiting, diarrhea, skin and eye irritation, } \\
\text { hyperpigmentation, thickening of the palms and soles (hyperkeratosis), } \\
\text { contact dermatitis, and skin sensitization. Impairment of peripheral } \\
\text { circulation and Raynaud's phenomenon have also been reported, and } \\
\text { inorganic arsenic is considered carcinogenic. }\end{array}$ & $\begin{array}{l}2 \mu \mathrm{g} / \mathrm{m}^{3} \text { ceiling } \\
\text { Ca }\end{array}$ & $10 \mu \mathrm{g} / \mathrm{m}^{3}$ TWA & $\begin{array}{c}10 \mu \mathrm{g} / \mathrm{m}^{3} \mathrm{TWA} \\
\mathbf{C a}\end{array}$ \\
\hline Cadmium & $\begin{array}{l}\text { Cadmium exposures can cause irritation of the lungs, irreversible lung } \\
\text { damage, and kidney damage. Occupational exposure to cadmium has been } \\
\text { implicated in a significant increase in prostate and respiratory tract cancer. } \\
\text { Other consequences of cadmium exposure include anemia, eosinophilia, } \\
\text { yellow discoloration of the teeth, rhinitis, occasional ulceration of the nasal } \\
\text { septum, damage to the olfactory nerve, and anosmia. }\end{array}$ & $\begin{array}{l}\text { Lowest feasible } \\
\text { concentration } \\
\text { Ca }\end{array}$ & $5 \mu \mathrm{g} / \mathrm{m}^{3} \mathrm{TWA}$ & $\begin{array}{l}10 \mu \mathrm{g} / \mathrm{m}^{3} \mathrm{TWA} \\
\text { inhalable } \\
\begin{array}{l}2 \mu \mathrm{g} / \mathrm{m}^{3} \mathrm{TWA} \\
\text { respirable }\end{array} \\
\quad \text { Ca }\end{array}$ \\
\hline Chromium & $\begin{array}{l}\text { Chromium }(\mathrm{Cr}) \text { exists in a variety of chemical forms and toxicity varies } \\
\text { among the different forms. For example, elemental chromium is relatively } \\
\text { non-toxic. Other chromium compounds may cause skin irritation, } \\
\text { sensitization, and allergic dermatitis. In the hexavalent form }(\mathrm{Cr}(\mathrm{VI})), \mathrm{Cr} \\
\text { compounds are corrosive, and possibly carcinogenic. Until recently, the less } \\
\text { water-soluble } \mathrm{Cr}(\mathrm{VI}) \text { forms were considered carcinogenic while the } \\
\text { water-soluble forms were not considered carcinogenic. Recent } \\
\text { epidemiological evidence indicates carcinogenicity among workers exposed } \\
\text { to soluble Cr(VI) compounds. Based on this new evidence, NIOSH } \\
\text { recommends that all } \mathrm{Cr}(\mathrm{VI}) \text { compounds be considered as potential } \\
\text { carcinogens. }\end{array}$ & $\begin{array}{c}\text { Cr(VI) } \\
0.001 \mathrm{mg} / \mathrm{m}^{3} \\
\text { TWA } \\
\text { Ca } \\
\text { Cr other than } \\
\text { Cr(VI) } \\
0.5 \mathrm{mg} / \mathrm{m}^{3} \mathrm{TWA}\end{array}$ & $\begin{array}{c}\text { Cr(VI) } \\
0.1 \mathrm{mg} / \mathrm{m}^{3} \\
\text { ceiling } \\
\\
\text { Cr(II) \& } \\
\mathbf{C r}(\mathrm{III}) \\
0.5 \mathrm{mg} / \mathrm{m}^{3} \mathrm{TWA} \\
\\
\text { Cr } \text { metal \& } \\
\text { insoluble salts } \\
1 \mathrm{mg} / \mathrm{m}^{3} \text { TWA }\end{array}$ & \begin{tabular}{|c} 
Cr(VI) \\
water-soluble \\
$0.05 \mathrm{mg} / \mathrm{m}^{3}$ \\
$\mathrm{TWA}, \mathrm{Ca}$ \\
\\
Cr(VI) \\
insoluble \\
$0.01 \mathrm{mg} / \mathrm{m}^{3}$ \\
$\mathrm{TWA}, \mathrm{Ca}$ \\
\\
Cr metal \& \\
Cr(III) \\
$0.5 \mathrm{mg} / \mathrm{m}^{3} \mathrm{TWA}$
\end{tabular} \\
\hline Lead & $\begin{array}{l}\text { Chronic lead exposure has resulted in nephropathy (kidney damage), } \\
\text { gastrointestinal disturbances, anemia, and neurologic effects. These effects } \\
\text { may be felt as weakness, fatigue, irritability, high blood pressure, mental } \\
\text { deficiency, or slowed reaction times. Exposure also has been associated } \\
\text { with infertility in both sexes and fetal damage. }\end{array}$ & $<100 \mu \mathrm{g} / \mathrm{m}^{3} \mathrm{TWA}$ & $50 \mu \mathrm{g} / \mathrm{m}^{3} \mathrm{TWA}$ & $50 \mu \mathrm{g} / \mathrm{m}^{3} \mathrm{TWA}$ \\
\hline
\end{tabular}




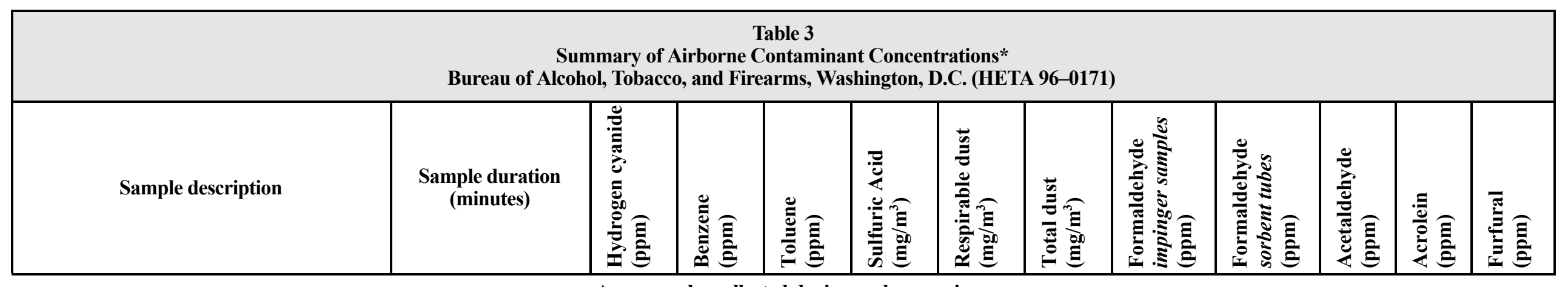

Area samples collected during each scenario

\begin{tabular}{|c|c|c|c|c|c|c|c|c|c|c|c|c|}
\hline Nelson Place fire scene & 47 & ND & - & - & trace & ND & 0.20 & - & ND & ND & ND & - \\
\hline Lamont Drive fire scene & 182 & 0.01 & - & - & trace & 0.10 & 0.33 & - & trace & 0.13 & 0.02 & - \\
\hline Living room scenario & $49(60)$ & 0.04 & trace & trace & trace & 0.36 & 0.92 & $0.06^{\wedge}$ & ND & trace & ND & ND \\
\hline Bedroom scenario & 50 & trace & trace & trace & trace $\dagger$ & 0.35 & 1.1 & 0.16 & trace & trace & ND & ND \\
\hline Office scenario & $38(34)$ & trace & trace & trace & trace & 1.2 & 5.3 & 0.18 & ND & trace & ND & trace \\
\hline
\end{tabular}

Personal breathing zone samples collected on investigators

\begin{tabular}{|c|c|c|c|c|c|c|c|c|c|c|c|c|}
\hline Living room scenario & 55 & - & - & - & - & - & - & - & ND & trace & ND & ND \\
\hline Living room scenario & 55 & - & - & - & 0.29 & - & - & - & - & - & - & - \\
\hline Living room scenario & 56 & trace & - & - & - & - & - & - & - & - & - & - \\
\hline Bedroom scenario & 62 & - & - & - & - & - & - & - & trace & trace & ND & trace \\
\hline Bedroom scenario & 62 & 0.03 & - & - & trace $\dagger$ & - & - & - & - & - & - & - \\
\hline Office scenario & 40 & - & - & - & trace $\dagger$ & - & - & - & ND & trace & ND & trace \\
\hline Office scenario & 40 & trace & trace & trace & - & - & - & - & - & - & - & - \\
\hline
\end{tabular}

*Analyses for xylene and styrene were also conducted; however, neither compound was detected. The minimum detectable concentrations (MDC) for xylene and styrene were 0.03 and 0.13 ppm, respectively, assuming a sample volume of 8.8 liters.

- Analysis for this particular contaminant was not performed on sample described.

() - Sample duration for impingers, if different than other samples.

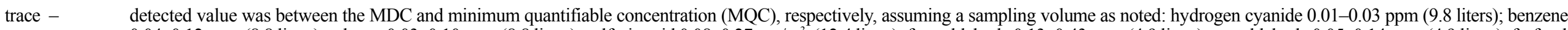

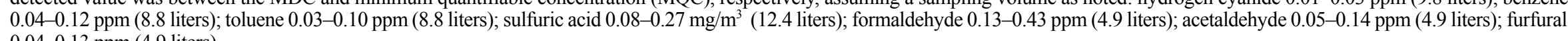
$0.04-0.13 \mathrm{ppm}$ (4.9 liters).

$\wedge$ Average of two samples collected during this scenario (0.05 and $0.06 \mathrm{ppm})$.

ND - not detected; below the analytical limit of detection.

$\dagger$ trace concentrations of hydrochloric acid ( $0.07-0.29 \mathrm{ppm})$ or hydrofluoric acid $(0.12-0.50 \mathrm{ppm})$ were detected on these samples collected during the office or bedroom scenarios, respectively. 
Table 4

Summary of Airborne Particle Size Distributions and Dust Concentrations Determined Using the Grimm Portable Dust Monitor Bureau of Alcohol, Tobacco, and Firearms, Washington, D.C. (HETA 96-0171)

\begin{tabular}{|c|c|c|c|c|c|c|}
\hline Sample description & $\begin{array}{c}\text { Concentration } \\
\text { Determined by } \\
\text { Grimm } \\
\left(\mathbf{m g} / \mathbf{m}^{3}\right)\end{array}$ & $\begin{array}{c}\text { Actual } \\
\text { Concentration } \\
\text { Determined } \\
\text { Gravimetrically } \\
\star \\
\left(\mathbf{m g} / \mathbf{m}^{3}\right)\end{array}$ & $\begin{array}{l}\text { Correction } \\
\text { Factor }\end{array}$ & $\begin{array}{c}\text { Peak } \\
\text { Concentration } \\
\text { Measured by } \\
\text { Grimm† } \\
\left(\mathbf{m g} / \mathbf{m}^{3}\right)\end{array}$ & $\begin{array}{c}\text { Mass Median } \\
\text { Aerodynamic } \\
\text { Diameter } \\
\text { (micrometers) }\end{array}$ & $\begin{array}{c}\text { Geometric Standard } \\
\text { Deviation }\end{array}$ \\
\hline Nelson Place fire scene & 0.7 & 0.5 & 0.68 & 6.4 & 9.8 & 2.1 \\
\hline Lamont Drive fire scene & 0.8 & 0.2 & 0.31 & 11.2 & 6.3 & 2.2 \\
\hline Living room scenario & 1.1 & 1.0 & 0.87 & 3.5 & 6.1 & 3.1 \\
\hline Bedroom scenario & 1.8 & 1.0 & 0.56 & 5.1 & 10.4 & 3.1 \\
\hline Office scenario & 11.7 & 8.7 & 0.74 & 31.6 & 11.7 & 2.5 \\
\hline
\end{tabular}

This concentration was calculated by obtaining the difference between the pre-and post-sampling weights of the 47 millimeter, teflon filter used in the Grimm portable dust monitor. This weight difference was then divided by the sample air volume to obtain the actual concentration. The sample volume was calculated using a flow rate of 1.2 liters per minute.

† Peak concentrations were mass corrected by multiplying the peak concentration measured with the Grimm and the listed correction factor.

$\mathbf{m g} / \mathbf{m}^{3}$ - milligrams per cubic meter of air 


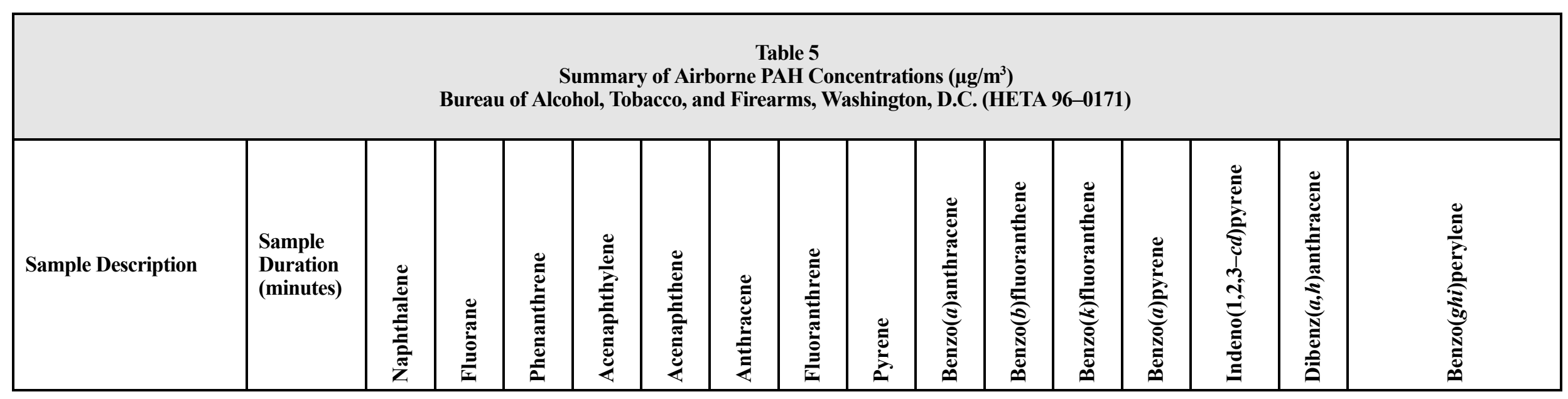

Residential Fire Scenes (2/12-13/97)

\begin{tabular}{|l|c|c|c|c|c|c|c|c|c|c|c|c|c|c|c|c|}
\hline Nelson Place fire scene & 47 & 30 & trace & trace & ND & ND & ND & ND & ND & ND & ND & ND & ND & ND & ND & ND \\
\hline Lamont Drive fire scene & 182 & 36 & 2.4 & trace & ND & ND & ND & ND & ND & ND & ND & ND & ND & ND & ND & ND \\
\hline Minimum Detectable Concentration & 3.1 & 0.4 & 0.1 & 8.7 & 2.6 & 0.22 & 0.44 & 0.35 & 0.22 & 0.44 & 0.17 & 0.35 & 0.44 & 0.87 & 1.3 \\
\hline Minimum Quantifiable Concentration & 10 & 1.4 & 0.4 & 29 & 8.7 & 0.70 & 1.4 & 1.1 & 0.70 & 1.4 & 0.57 & 1.1 & 1.4 & 2.9 & 4.3 \\
\hline
\end{tabular}

Ft. Belvoir Staged Fire Scenes (6/3/97)

\begin{tabular}{|l|c|c|c|c|c|c|c|c|c|c|c|c|c|c|c|c|}
\hline Living room scenario & 49 & 99 & 7.4 & 3.5 & 44 & 12 & 0.65 & 0.66 & 0.31 & 0.14 & trace & 0.06 & 0.16 & ND & trace & trace \\
\hline Bedroom scenario & 50 & 200 & 18 & 6.3 & 100 & 65 & 0.30 & 0.44 & 0.29 & 0.09 & trace & trace & 0.11 & ND & trace & \\
\hline Office scenario & 38 & 132 & 11 & 8.0 & 66 & 20 & 1.6 & 1.1 & 0.74 & 0.29 & 0.21 & 0.12 & 0.39 & trace & trace & \\
\hline Minimum Detectable Concentration & 4.4 & 0.9 & 0.7 & 8.8 & 3.3 & 0.01 & 0.02 & 0.01 & 0.01 & 0.03 & 0.02 & 0.02 & 0.11 & 0.04 & \\
\hline Minimum Quantifiable Concentration & 16 & 2.9 & 2.1 & 31 & 12 & 0.03 & 0.07 & 0.04 & 0.05 & 0.12 & 0.06 & 0.06 & 0.35 & 0.15 & 0.03 \\
\hline
\end{tabular}

$\mu \mathrm{g} / \mathrm{m}^{3}-\quad$ micrograms per cubic meter of air

trace - detected value was between the minimum detectable concentration (MDC) and minimum quantifiable concentration (MQC). These values are listed above and were calculated assuming a sampling volume of 229 liters for the residential fire scenes and 91 liters for the Ft. Belvoir staged fire scenes. The MDCs and MQCs are presented separately because the analytical limits of detection and quantitation differed significantly for the two sets of analyses.

ND - not detected; below the analytical limit of detection and corresponding MDC. 
Table 6

Summary of Analytical Limits of Detection and Quantitation with Corresponding

Minimum Detectable and Quantifiable Concentrations

Bureau of Alcohol, Tobacco, and Firearms, Washington, D.C. (HETA 96-0171)

\begin{tabular}{|c|c|c|c|c|c|}
\hline Analyte & $\begin{array}{c}\text { LOD } \\
\text { ( } \mu \mathrm{g} / \mathrm{sample})\end{array}$ & $\begin{array}{c}\text { LOQ } \\
\text { ( } \mu \mathrm{g} / \mathrm{sample})\end{array}$ & $\begin{array}{c}\text { MDC } \\
\left(\text { ppm* }^{*}\right)\end{array}$ & $\begin{array}{c}\text { MQC } \\
\left(\text { ppm*) }^{*}\right)\end{array}$ & $\begin{array}{c}\text { Sample Air } \\
\text { Volume } \\
\text { (liters) }\end{array}$ \\
\hline Formaldehyde (Fire Scenes \#1 \& 2) & 0.3 & 1.0 & 0.01 & 0.04 & 18.2 \\
\hline Formaldehyde (Fire Scenes \#3, 4, \& 5) & 0.8 & 2.6 & 0.13 & 0.43 & 4.9 \\
\hline Acetaldehyde (Fire Scenes \#1 \& 2) & 0.9 & 3.0 & 0.03 & 0.09 & 18.2 \\
\hline Acetaldehyde (Fire Scenes \#3, 4, \& 5) & 0.4 & 1.2 & 0.05 & 0.14 & 4.9 \\
\hline Acrolein (Fire Scenes \#1 \& 2) & 0.3 & 1.0 & 0.01 & 0.02 & 18.2 \\
\hline Acrolein (Fire Scenes \#3, 4, \& 5) & 1.0 & 4.5 & 0.09 & 0.40 & 4.9 \\
\hline Furfural (Fire Scenes \#3, 4, \& 5) & 0.8 & 2.6 & 0.04 & 0.13 & 4.9 \\
\hline Hydrogen Cyanide (Fire Scenes \#1 \& 2) & 0.1 & 0.35 & 0.002 & 0.009 & 36.4 \\
\hline Hydrogen Cyanide (Fire Scenes \#3, 4, \& 5) & 0.1 & 0.35 & 0.01 & 0.03 & 9.8 \\
\hline Sulfuric Acid (Fire Scenes \#1 \& 2) & 2.0 & 6.7 & $0.05 \mathrm{mg} / \mathrm{m}^{3}$ & $0.18 \mathrm{mg} / \mathrm{m}^{3}$ & 36.4 \\
\hline Sulfuric Acid (Fire Scenes \#3, 4, \& 5) & 1.0 & 3.4 & $0.10 \mathrm{mg} / \mathrm{m}^{3}$ & $0.35 \mathrm{mg} / \mathrm{m}^{3}$ & 9.8 \\
\hline Nitric Acid (Fire Scenes \#1 \& 2) & 2.0 & 6.7 & 0.02 & 0.07 & 36.4 \\
\hline Hydrochloric Acid (Fire Scenes \#3, 4, \& 5) & 1.0 & 4.2 & 0.07 & 0.29 & 9.8 \\
\hline Hydrofluoric Acid (Fire Scenes \#3, 4, \& 5) & 1.0 & 4.0 & 0.12 & 0.50 & 9.8 \\
\hline Benzene (Fire Scenes \#3, 4, \& 5) & 0.001 & 0.033 & 0.04 & 0.12 & 8.8 \\
\hline Toluene (Fire Scenes \#3, 4, \& 5) & 0.001 & 0.033 & 0.03 & 0.10 & 8.8 \\
\hline
\end{tabular}

*Unless otherwise noted.

LOD - Limit of Detection

$\boldsymbol{\mu g} / \mathbf{s a m p l e}$ - micrograms per sample

LOQ - Limit of Quantitation

MDC - Minimum Detectable Concentration

ppm - parts per million

MQC - Minimum Quantifiable Concentration

$\mathbf{m g} / \mathbf{m}^{3}$ - milligrams per cubic meter of air 


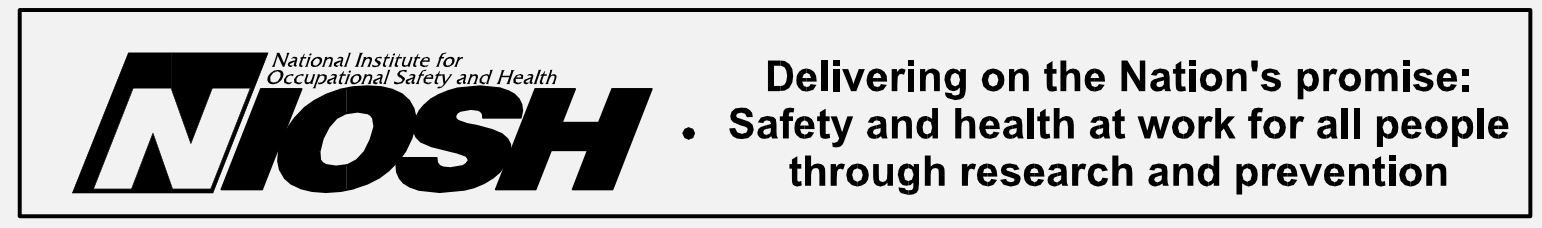

